\title{
Apoptotic crosstalk of TNF receptors: TNF-R2-induces depletion of TRAF2 and IAP proteins and accelerates TNF-R1-dependent activation of caspase-8
}

\author{
Mariola Fotin-Mleczek1,*, Frank Henkler, ${ }^{1, *}$, Dierk Samel ${ }^{1}$, Monica Reichwein ${ }^{1}$, Angelika Hausser ${ }^{1}$, \\ Ingela Parmryd ${ }^{2}$, Peter Scheurich ${ }^{1}$, Johannes A. Schmid ${ }^{3}$ and Harald Wajant ${ }^{1, \neq}$ \\ ${ }^{1}$ Institute of Cell Biology and Immunology, University of Stuttgart, Allmandring 31, 70569 Stuttgart, Germany \\ ${ }^{2}$ National Institute for Medical Research, Division of Membrane Biology, The Ridgeway, Mill Hill, London NW7 1AA, UK \\ 3 Institut für Gefäßbiologie und Thromboseforschung, University of Vienna, 1235 Vienna, Austria \\ *These authors contributed equally to this work \\ $\ddagger$ Author for correspondence (e-mail: harald.wajant@po.uni-stuttgart.de) \\ Accepted 27 March 2002 \\ Journal of Cell Science 115, 2757-2770 (2002) () The Company of Biologists Ltd
}

\section{Summary}

We have recently shown that stimulation of TNF-R2 selectively enhances apoptosis induction by the death receptor TNF-R1. Here, we demonstrate that stimulation of CD30 or CD40 also leads to selective enhancement of TNF-R1-induced cell death. Enhancement of apoptosis was correlated with the depletion of endogenous TRAF2 within 1 to 6 hours. Selective prestimulation of TNF-R2 for several hours inhibited TNF-R2-induced activation of the antiapoptotic NF- $\kappa$ B pathway up to $90 \%$ and dramatically enhanced apoptosis induction by this receptor. When both TNF-receptors were stimulated simultaneously, TNF-R1induced NF- $\kappa B$ activation remained unaffected but TNFR1-induced apoptosis was still significantly enhanced. Compared with FasL-induced cell death TNF-R1-induced activation of caspase-8 was significantly weaker and delayed. Costimulation or prestimulation of TNF-R2 enhanced caspase-8 processing. Life cell imaging and confocal microscopy revealed that both TNF-R1 and TNF$R 2$ recruited the anti-apoptotic factor cIAP1 in a TRAF2dependent manner. Thus, TNF-R2 may compete with TNF$R 1$ for the recruitment of newly synthesized TRAF2-bound anti-apoptotic factors, thereby promoting the formation of a caspase-8-activating TNF-R1 complex. Hence, TNF-R2 triggering can interfere with TNF-R1-induced apoptosis by inhibition of NF- $\kappa$ B-dependent production of antiapoptotic factors and by blocking the action of antiapoptotic factors at the post-transcriptional level.

Key words: Caspase-8, Cell death, TNF, TNF-R2, TRAF2

\section{Introduction}

Tumor necrosis factor (TNF) exerts its biological functions by interactions with two members of the TNF receptor superfamily, namely TNF-R1 and TNF-R2. The cytoplasmic tail of TNF-R1 contains a death domain (DD), which is essential for induction of apoptosis. However, this motif is missing in TNF-R2 and the function of the latter receptor is poorly understood. TNF occurs in two bioactive forms. In its membrane-bound form (mTNF) TNF stimulates TNF-R1 and TNF-R2, whereas in its proteolytically processed soluble form (sTNF) TNF predominantly signals via TNF-R1 (Grell et al., 1995; Grell et al., 1998). A variety of reports indicate that TNFR1 triggers the apoptotic program by sTNF-induced sequential recruitment of the adaptor protein TRADD, the TRADDinteracting adaptor protein FADD and the FADD-interacting initiator caspase FLICE/caspase-8 (Locksley et al., 2001; Wallach et al., 1999). However, activation of TNF-R1 also results in a strong activation of NF- $\mathrm{\kappa B}$ and induction of NF-кB-regulated anti-apoptotic factors by a pathway including TRADD, TRAF2, RIP (for a review, see Wajant et al., 1999; Wajant et al., 2001) and MEKK3 (Yang et al., 2001). Consequently, TNF-R1-induced apoptosis typically develops only when the anti-apoptotic NF-кB response is downregulated. For example, mice deficient in components of the TNF-induced NF-кB response (RIP, TRAF2, IKK $\beta$, IKK $\gamma$, p65, MEKK3) die because of massive liver apoptosis, and embryonal fibroblasts derived from these mice show enhanced sensitivity to TNF-induced apoptosis (Beg et al., 1995; Kelliher et al., 1998; Li et al., 1999; Makris et al., 2000; Rudolph et al., 2000; Schmidt-Supprian et al., 2000; Tada et al., 2001; Tanaka et al., 1999).

After ambiguous results concerning the apoptosis-inducing capabilities of the non-death-domain-containing receptor TNFR2 (Heller et al., 1992; Tartaglia et al., 1993), the use of agonistic TNF-R2-specific antibodies clearly showed that exclusive triggering of this receptor is sufficient in some cells to induce cell death (Bigda et al., 1994; Grell et al., 1993; Medvedev et al., 1994). However, stimulation of TNF-R2 does not directly engage the apoptotic program, but relies on the induction of endogenous TNF, which subsequently activates TNF-R1 (Grell et al., 1999; Vercammen et al., 1995). In addition, activation of TNF-R2 can lead to a tremendous enhancement of TNF-R1-induced cell death independent of endogenous TNF by a TRAF2-dependent intracellular mechanism (Chan and Lenardo, 2000; Declercq et al., 1998; 
Duckett and Thompson, 1997; Vandenabeele et al., 1995; Weiss et al., 1997).

Here, we show that stimulation of TNF-R2 results in a strong recruitment of TRAF2 that is accompanied by a strong depletion of cytosolic TRAF2. Moreover, we give evidence that TNF-R1 and TNF-R2 can compete for TRAF2-dependent recruitment of the anti-apoptotic proteins cIAP1 and cIAP2, which suggests that TNF-R2-induced TRAF2-mediated depletion of cIAP $1 / 2$ underlies the apoptotic TNF receptor crosstalk. In accordance with this model we show that TNFR1-induced activation of procaspase-8 is slower than TNF-R2induced TRAF2 depletion.

\section{Materials and Methods}

\section{Cells, plasmids, antibodies and ligands}

The human rhabdomyosarcoma cell line Kym1 was a gift from $\mathrm{M}$. Sekiguchi (University of Tokyo, Japan) and maintained in ClickRPMI medium with $10 \%$ heat-inactivated fetal calf serum (Biochrom, Berlin, Germany). The human colon carcinoma cell line Colo205 and HeLa cells were from the American Type Culture Collection (Rockville, MD) and maintained in RPMI 1640 medium supplemented with 5\% heat-inactivated fetal calf serum (Biochrom). The Jurkat-TNF-R2 transfectant was generously supplied by F. Pimentel-Muinos and B. Seed (Massachusetts General Hospital, MA) and maintained in RPMI 1640 medium with $10 \%$ heat-inactivated fetal calf serum (Pimentel-Muinos and Seed, 1999). HeLa transfectants stably expressing TNF-R2 were as described elsewhere [HeLa-TNF-R2 (Weiss et al., 1997)]. HeLa-CD40 cells were a kind gift of H. Engelmann (University of Munich, Germany) (Hess and Engelmann, 1996).

For generation of HeLa-CD30 cells, HeLa cells were stably transfected with a CD30 expression plasmid. After G418 selection more than 100 primary clones were pooled, expanded and enriched for cells with high expression of cell surface CD30 by three rounds of cell sorting using a FACStar Plus (Becton Dickinson, San Jose, CA) and the CD30-specific mAb Ki-1. Expression plasmids encoding TRAF2-GFP, TRAF2-YFP, TNF-R1-YFP, cIAP1(NT)-GFP and cIAP2(NT)-GFP were generated by proofreading PCR-based amplification of the corresponding cDNA regions from HeLa cDNA and insertion of the obtained amplicons into the pEGFP-N1 and pEYFP-N1 vectors (Clontech, Heidelberg, Germany). Forward primers contained a BamHI (BglII for cIAP1 plasmids; NheI for TNFR1 plasmid) site and reverse primers contained a SacII (SacI for TNF$\mathrm{R} 1$ plasmids) site in their $5^{\prime}$ overhangs to allow oriented insertion into the respective sites of the pEGFP-N1 and pEYFP-N1 vectors.

The deletion mutant of TRAF2, where the C-terminal TRAF domain is substituted by GFP (TRAF2-NT-GFP), was generated by proofreading PCR based amplification of a cDNA fragment encoding amino acids 1-272 of TRAF2 and insertion of the obtained amplicon into pEGFP-N1. Again primers were used with BamHI and SacII overhangs to allow in frame insertion into the BglII and SacII sites of pEGFP-N1. To generate the N-terminal deletion mutant of TRAF2 in which the TRAF domain of the molecule was C-terminally fused to GFP, a cDNA fragment comprising TRAF2 amino acids 186-501 was amplified by proofreading PCR with HeLa cDNA as template. The forward primers used contained a BamHI site and the reverse primers used contained a NotI site. The BamHI and Not I sites were used for subsequent cloning of the amplicon in a modified version of the recently described pcDNA3.1-GFP $\triangle$ FADD expression construct (Wajant et al., 1998). In this modified version a BamHI/BglII hybrid site between GFP and $\triangle$ FADD was restored to a complete BamHI site, and a BamHI site $5^{\prime}$ to the start codon of the fusion protein was destroyed. Thus, in this modified version the $\triangle F A D D$ part could be substituted by the respective TRAF2 amplicon.
The expression construct CFP-TRADD-DD was obtained by introducing a respective cDNA amplicon into the $B g l \mathrm{II}$ and $\mathrm{SacII}$ sites of pECFP-N1. The expression vector pECFP-Mem encoding ECFP targeted to cellular membranes by 20 amino acids of neuromodulin was from Clontech (Heidelberg, Germany). Rabbit polyclonal antiTNF-R2 IgG was already described elsewhere (Grell et al., 1995). Flag-tagged recombinant soluble TRAIL, FasL and CD40L were generously supplied by P. Schneider and J. Tschopp (University of Lausanne, Switzerland). If not otherwise stated, all other reagents were from Sigma (Deisenhofen, Germany).

\section{Cytotoxicity assay}

Cells were seeded in 96 -well microtiter plates $\left(20 \times 10^{3} \mathrm{HeLa}\right.$ cells per well; $15 \times 10^{3} \mathrm{Kym} 1$ cells per well) and cultivated over night. The next day HeLa cells were treated with $2.5 \mu \mathrm{g} / \mathrm{ml}$ cycloheximide and $\mathrm{Kym} 1$ cells remained untreated. After 1 hour, TNF or FasL were added and costimulation of TNF-R2, CD30 or CD40 was performed as follows: TNF-R2 was stimulated with an agonistic TNF-R2-specific rabbit IgG fraction $(2 \mu \mathrm{g} / \mathrm{ml})$; CD40 was stimulated with Flag-tagged recombinant soluble CD40L $(100 \mathrm{ng} / \mathrm{ml})$ crosslinked with the Flagspecific mAb M2 (1 $\mu \mathrm{g} / \mathrm{ml}$; Sigma); and CD30 was stimulated with the agonistic CD30-specific mAb Ki-1 ( $3 \mu \mathrm{g} / \mathrm{ml})$. FasL was used as Flag-tagged recombinant soluble molecule crosslinked with $1 \mu \mathrm{g} / \mathrm{ml}$ M2 (Schneider et al., 1998). After an additional 18 hours, cells were washed with PBS followed by crystal violet staining (20\% methanol, $0.5 \%$ crystal violet) for 15 minutes. The wells were washed with $\mathrm{H}_{2} \mathrm{O}$ and air-dried. The dye was eluted with methanol for 15 minutes and optical density at $550 \mathrm{~nm}$ was measured with a R5000 ELISA plate reader (Dynatech, Guernsey, GB).

\section{Transient transfection and reporter gene assays}

HeLa-TNFR2 cells were seeded in 96-well plates with a density of $1.5 \times 10^{4}$ cells per well. The next day cells were transfected with 200 $\mathrm{ng} / \mathrm{well}$ of the indicated expression plasmid, $35 \mathrm{ng} / \mathrm{well}$ of a luciferase reporter plasmid driven by three consensus NF- $\mathrm{BB}$ sites and $15 \mathrm{ng} / \mathrm{ml}$ of $\beta$-galactosidase expression vector driven by the SV40 promoter using the Superfect reagent (Qiagen, Hilden, Germany) according to the manufacturer's instructions. After 1 day, cells were stimulated as indicated and cell extracts were prepared by the addition of $50 \mu \mathrm{l}$ of luciferase lysis solution (Galactolight-Kit, Tropix, Bedford, MA) and one freeze-thaw cycle. A portion of the extracts $(25 \mu \mathrm{l})$ was mixed with $50 \mu \mathrm{l}$ of luciferase substrate (Luciferase Assay System, Promega) and the luminescence was determined in the single photon mode using an Anthos microplate luminometer (Lucy 2). In parallel, $25 \mu 1$ of each cell extract was incubated for 1 hour with a 1:100 dilution of Galacton substrate in reaction buffer and mixed with $100 \mu \mathrm{l}$ of accelerator II solution to determine relative $\beta$-galactosidase activity (GalactolightKit) again with the Anthos microplate luminometer (Lucy 2). Luciferase activities were normalized based on the $\beta$-galactosidase activities.

\section{Western blot analysis}

For detection of IкB, caspase- 8 and caspase- 3 pellets of $2 \times 10^{6}$ cells were lysed in lysis buffer containing $150 \mathrm{mM} \mathrm{NaCl}, 50 \mathrm{mM}$ Tris- $\mathrm{HCl}$, $\mathrm{pH} 8.0,1 \% \mathrm{NP}-40$ and $0.1 \% \mathrm{SDS}$, and lysates were clarified by centrifugation $\left(4^{\circ} \mathrm{C}, 10\right.$ minutes, $\left.13,000 \mathrm{rpm}\right)$. Protein concentrations were determined using a Bradford based protein assay (Bio-Rad) and equal amounts of protein were resolved by SDS-polyacrylamide gel electrophoresis and transferred on nitrocellulose membranes. After blocking with 5\% nonfat dry milk in PBS-Tween-20 (0.05\%) for 1 hour, membranes were probed with the indicated antibodies. The antibody-antigen complexes were finally detected using alkaline phosphatase labeled secondary antibodies $(0.1 \mu \mathrm{g} / \mathrm{ml}$, Sigma-Aldrich, Deisenhofen, Germany) and BCIP and NBT as substrates. For 
analyzing total cellular TRAF2 content by western blot, cell pellets were directly solubilized in Laemmli sample buffer $\left(10^{6}\right.$ cells per 50 $\mu l$ buffer) by help of a sonicator. The equivalent of $0.8 \times 10^{6}$ cells per group was applied on the gel.

For preparation of TRAF2 cytoplasmic extracts and the

A
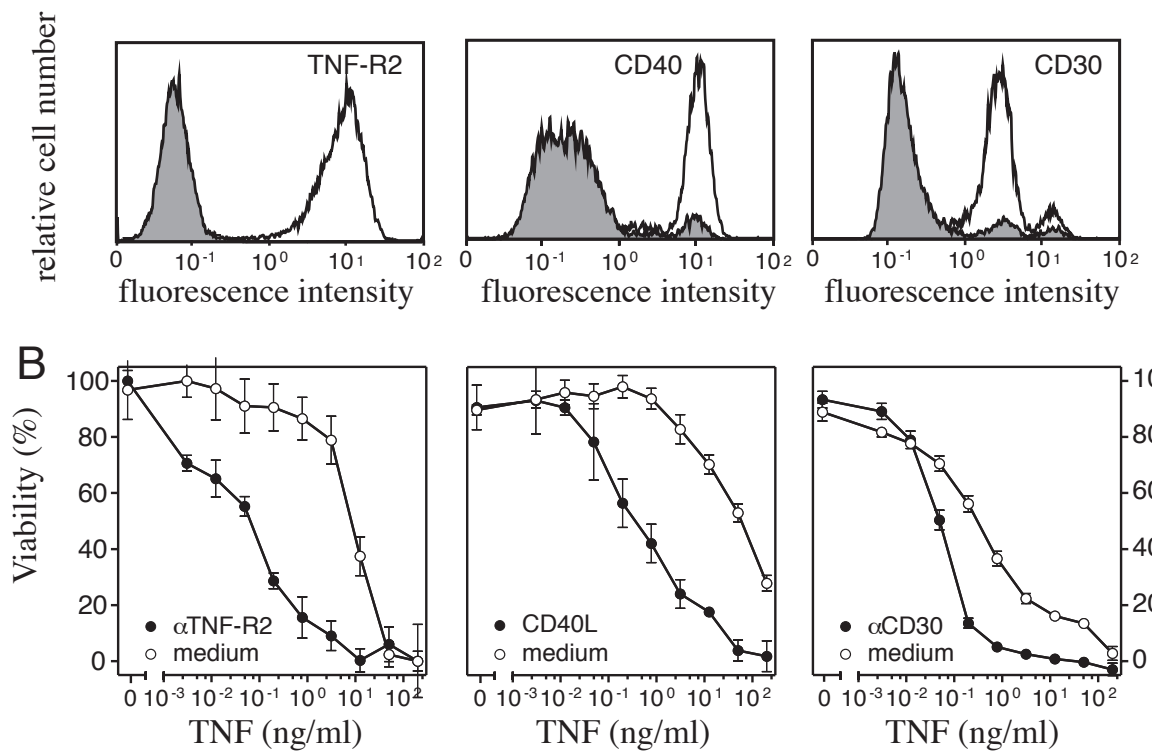

$\mathrm{TNF}(\mathrm{ng} / \mathrm{ml})$
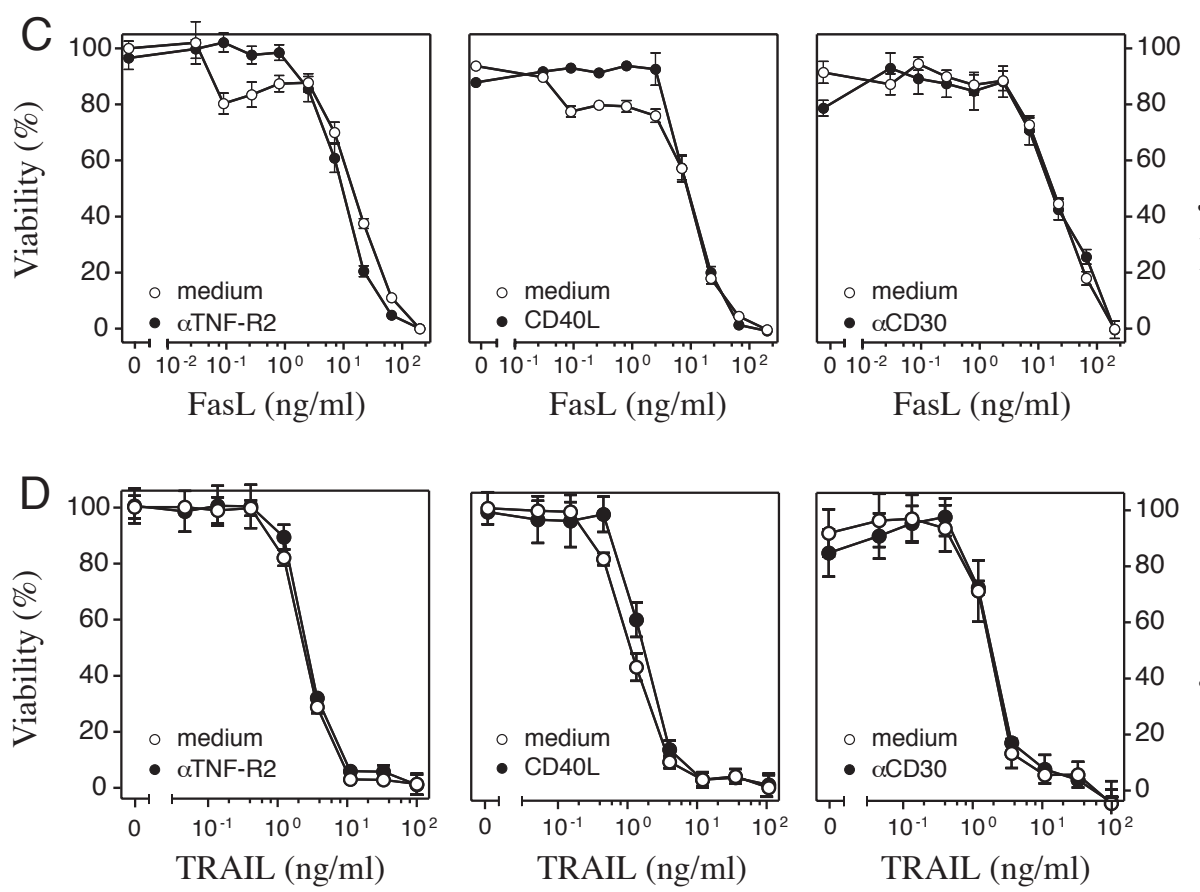

Fig. 1. Enhancement of TNF-R1-induced cell death by costimulation of TNF-R2, CD40 or CD30. (A) HeLa transfectants stably expressing TNF-R2, CD40 or CD30 were analyzed for expression of these receptors by FACS analysis with receptor-specific monoclonal antibodies. (B,C) HeLa-TNFR2, -CD40 and -CD30 cells were grown in 96-well microtiter plates $\left(15 \times 10^{3}\right.$ cells/well $)$ and cultured overnight at $37^{\circ} \mathrm{C}$. The next day the cells were treated overnight in triplicates with TNF (B), crosslinked FasL (C) or crosslinked TRAIL (D) in the presence of CHX $(2.5 \mu \mathrm{g} / \mathrm{ml})$ with (O) or without $(O)$ costimulation of the respective TRAF2-interacting receptor. TNF-R2 was triggered with a polyclonal TNF-R2-specific IgG preparation $(2 \mu \mathrm{g} / \mathrm{ml})$, CD30 was stimulated with the agonistic mAb Ki-1 (3 $\mu \mathrm{g} / \mathrm{ml})$ and CD40 was activated with soluble Flag-tagged CD40L (100 $\mathrm{ng} / \mathrm{ml})$ crosslinked with the anti-Flag mAb M2 $(1 \mu \mathrm{g} / \mathrm{ml})$. Finally, viable cells were quantified by crystal violet staining.

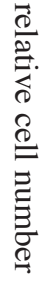

corresponding detergent-insoluble fraction cells were lysed in 150 centrifugation $\left(4^{\circ} \mathrm{C}, 30\right.$ minutes, $\left.10,000 \mathrm{~g}\right)$. The obtained detergenttwice and solubilized in Laemmli sample determined using a Bradford based protein assay (Bio-Rad) and equal amounts of protein (100 $\mu \mathrm{g}$ cytoplasmic extract or the corresponding amount of insoluble pellet) were resolved by SDSPAGE and analyzed by western blotting. Anti-caspase- $3 \mathrm{mAb}$ clone 19 was from Transduction Laboratories (Heidelberg, Germany) and anti-IкB was from Santa Cruz (Heidelberg, Germany). The anticaspase- $8 \mathrm{mAb}$ was a kind gift from Klaus Schulze-Osthoff (University of Tübingen, Germany).

\section{Gelfiltration analysis of TRAF2 containing complexes}

Cells $\left(100-300 \times 10^{6}\right)$ were treated with the reagents of interest for the indicated times and subsequently scraped with a rubber policeman into the medium. Cells were washed in an ice-cold solution containing $50 \mathrm{mM}$ Tris, $\mathrm{pH}$ 7.4, $400 \mathrm{mM} \mathrm{NaCl}$ and $10 \%$ glycerol, and the cell pellet was resupended in 0.5-1fold its volume of the same ice-cold solution. All the following procedures were performed on ice or at $4^{\circ} \mathrm{C}$. Cells were lysed with Nonident-P40 to a final concentration of $0.1 \%$ and a protease inhibitor cocktail (Boehringer Mannheim, Germany) was added according to the recommendations of the supplier. The lysates were cleared by centrifugation $\left(8000 \mathrm{~g}, 10\right.$ minutes, $\left.4^{\circ} \mathrm{C}\right)$ and the S-100 supernatants were obtained by centrifugation at $100,000 \mathrm{~g}$ for 1 hour in a TL-100 rotor at $4^{\circ} \mathrm{C}$ (Beckman, Munich, Germany). $200 \mu \mathrm{l}$ of the S-100 supernatants were then separated by size exclusion chromatography on a Superdex 200 HR10/30 column (Pharmacia, Freiburg, Germany) in $50 \mathrm{mM}$ Tris, $400 \mathrm{mM} \mathrm{NaCl}$ and $10 \%$ glycerol, $\mathrm{pH} 7.4$ at 0.5 $\mathrm{ml} /$ minute. Samples were collected in fractions of $0.5 \mathrm{ml}$ and analyzed by immunoblotting with a polyclonal rabbit TRAF2-specific IgG fraction (Santa Cruz). The column was previously calibrated with thyroglobulin $(663 \mathrm{kDa})$, apoferritin $(443 \mathrm{kDa})$, alcohol dehydrogenase (150 kDa), bovine serum albumin $(66 \mathrm{kDa})$, carbonic anhydrase $(29 \mathrm{kDa})$ and cytochrome c (12.4 kDa), all purchased from Sigma.

Immunofluorescence and confocal microscopy

Transfected cells were fixed onto 

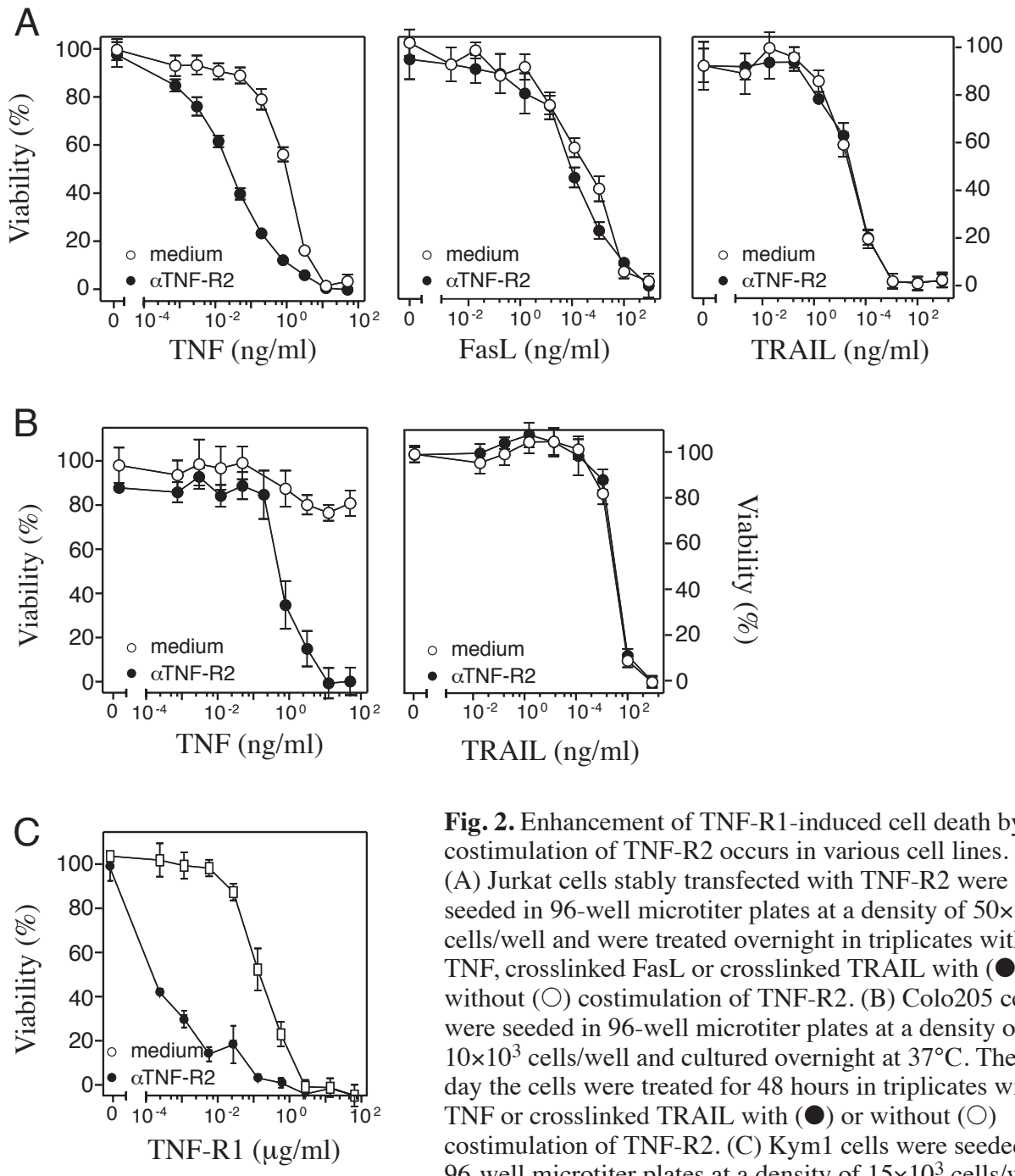

Fig. 2. Enhancement of TNF-R1-induced cell death by costimulation of TNF-R2 occurs in various cell lines. (A) Jurkat cells stably transfected with TNF-R2 were seeded in 96-well microtiter plates at a density of $50 \times 10^{3}$ cells/well and were treated overnight in triplicates with TNF, crosslinked FasL or crosslinked TRAIL with () or without $(\bigcirc)$ costimulation of TNF-R2. (B) Colo205 cells were seeded in 96-well microtiter plates at a density of $10 \times 10^{3}$ cells/well and cultured overnight at $37^{\circ} \mathrm{C}$. The next day the cells were treated for 48 hours in triplicates with TNF or crosslinked TRAIL with $(-)$ or without $(\bigcirc)$ costimulation of TNF-R2. (C) Kym1 cells were seeded in 96-well microtiter plates at a density of $15 \times 10^{3}$ cells/well and cultured overnight at $37^{\circ} \mathrm{C}$. The next day the cells were treated overnight in triplicates with the TNF-R1-specific agonistic mAb Htr1 with (ם) or without $(\square)$ costimulation of TNF-R2. As stimulation of TNF-R2 results in Kym1 cells in significant induction of endogenous TNF (Grell et al., 1999), the action of endogenous TNF was suppressed by addition of TNF-R1-Fc $(10 \mu \mathrm{g} / \mathrm{ml})$ and TNF-R1 triggering was aquired by the agonistic mAb Htr1c. Viable cells were quantified in all experiments by the MTT method.

coverslips in $3 \%$ paraformaldehyde, permeablized with $0.1 \%$ NP-40 for 10 minutes and blocked for a further 10 minutes with $\mathrm{PBS} / 1 \%$ BSA. Primary rabbit antisera specific for Lck and TNF-R2 were diluted 1:150 in TBST (150 mM NaCl, $50 \mathrm{mM}$ Tris- $\mathrm{HCl} \mathrm{pH} 8.0,0.1 \%$ Tween-20) and applied for 1 hour. Cells were then washed in PBS/0.05\% Tween-20 for 15 minutes, incubated for 45 minutes with rabbit-specific antisera (diluted 1:200) conjugated with AlexaFluor 546 (A-11060), washed and mounted onto microscope slides. Alternatively, cells expressing GFP fusion proteins were maintained in a conditioned chamber $\left(37^{\circ} \mathrm{C}, 5 \% \mathrm{CO}_{2}\right)$ for up to 2 hours on the microscope stage. Fluorescent specimens were analyzed with a Leica SP2 confocal microscope and photographed using the Leica TCS software.

\section{Results}

Costimulation of TNF-R2, CD30 and CD40 enhances sTNF- but not FasL- and TRAIL-mediated cell death

It has been shown that stimulation of TNF-R2 (Weiss et al.,
1997; Declercq et al., 1998; Chan and Lenardo, 2000) or CD40 (Hess and Engelmann, 1996) as well as transient overexpression of a constitutive active form of CD30 (Arch et al., 2000; Duckett and Thompson, 1997) enhance TNFR1-induced cell death. To clarify whether these receptors use related mechanisms for the enhancement of TNF-R1-mediated cell death, HeLa transfectants stably overexpressing these receptors were analyzed (Fig. 1A). As shown in Fig. 1B, costimulation of TNFR2 and CD40 and, to a lesser extent, costimulation of CD30 enhanced TNF-R1-dependent cell death, which was induced by use of soluble TNF. There was no significant induction of apoptosis by selective stimulation of TNFR2, CD30 and CD40 under the conditions used, excluding the possibility that these apoptotic effects are significantly based on the induction of endogenous TNF that had been described for these receptors in other systems (Grell et al., 1999; Vercammen et al., 1995). In all cases, induction of apoptosis by FasL and TRAIL, which both use the same FADD- and caspase8-dependent pathway as that used by TNF-R1, was not affected by costimulation of these receptors (Fig. 1C,D). For TNF-R2 this specificity has already been described elsewhere (Weiss et al., 1997). TNF-R2-mediated enhancement of TNF-R1-induced cell death was also observed in Jurkat cells stably transfected with TNF-R2 (Fig. 2A), as well as in Colo205 (Fig. 2B) and Kym1 cells (Fig. 2C). Together, these data point towards a principal mechanism by which TNF-R2, CD40 and CD30 affect formation of the TNF-R1-related death inducing signaling complex.

\section{TNF-R2 stimulation depletes high molecular mass TRAF2-containing complexes}

It has been shown that the transient overexpression of TNF-R2 or CD30 degraded co-transfected TRAF2 (Duckett and Thompson, 1997). Owing to the importance of TRAF2 for TNF-R1-mediated NF-KB activation (Devin et al., 2000; Devin et al., 2001; Tada et al., 2001), receptor-induced degradation of TRAF2 may account for the enhancement of TNF-R1induced cell death by triggering of CD30, CD40 and TNF-R2. We therefore analyzed endogenous TRAF2 levels upon selective stimulation of TNF-R2 with agonistic mAbs. For this 

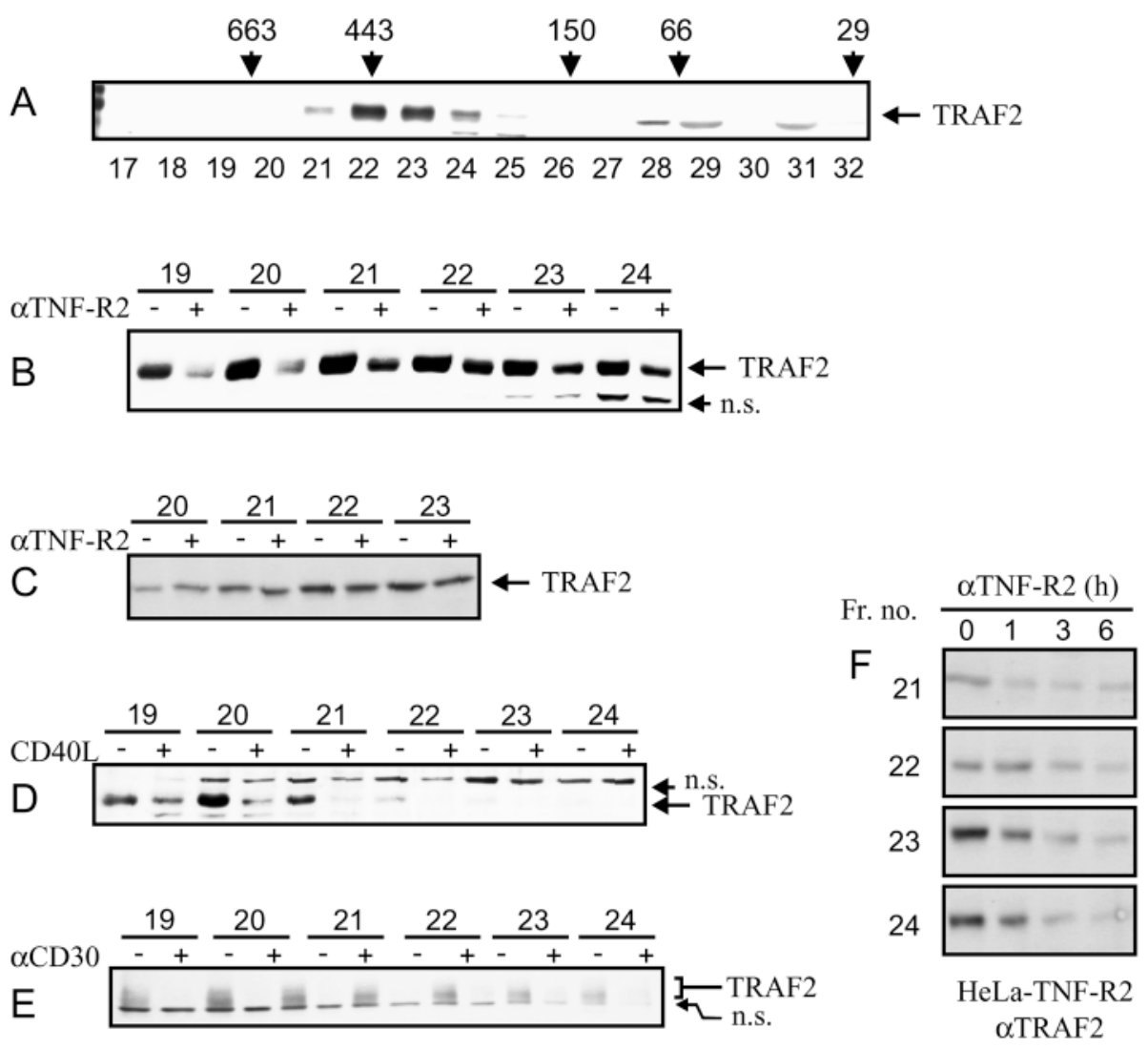

G

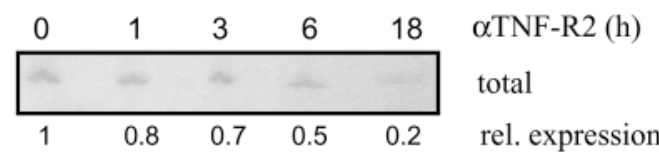

$\mathrm{H} \quad \alpha \mathrm{TRAF} 2$
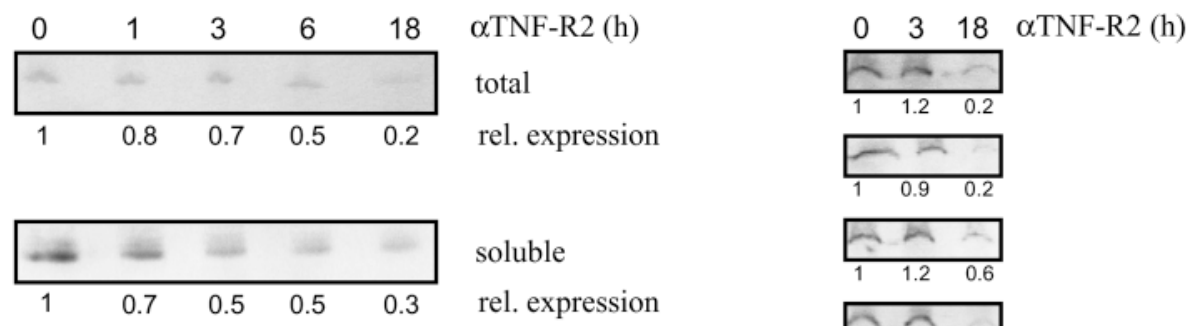

soluble

rel. expression

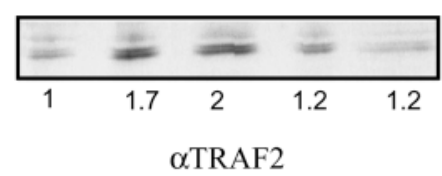

DIC fraction

rel. expression
Fig. 3. Receptor-induced depletion of cytoplasmic TRAF2. (A) Cell lysate $(200 \mu \mathrm{l})$ of untreated HeLa-TNF-R2 cells were separated by size exclusion chromatography on a HR10/30 Superdex 200 column and the fractions $(0.5 \mathrm{ml})$ were analyzed by immunoblotting with a polyclonal TRAF2-specifc rabbit antiserum. Elution volumes of molecular mass standards are indicated above. (B,C) HeLa-TNF-R2 cells (B) and HeLa cells expressing a deletion mutant of TNF-R2 lacking the entire cytoplasmic domain $(\mathrm{C})$ were stimulated for 6 hours with an agonistic TNF-R2-specific rabbit $\mathrm{IgG}$ fraction or remained untreated. Cell lysates $(200 \mu \mathrm{l})$ derived from these groups were separated by size exclusion chromatography and corresponding fractions of stimulated $(+)$ and unstimulated (-) cells were compared with respect to TRAF2 recovery by immunoblotting. (D,E) HeLa-CD40 (D) and HeLa-CD30 (E) cells were stimulated for 6 hours with crosslinked soluble CD40L $(100 \mathrm{ng} / \mathrm{ml})$ and the CD30-specific mAb Ki-1 (3 $\mu \mathrm{g} / \mathrm{ml})$, respectively, or remained untreated. The lysates were then analyzed as described in B and C. (F) Lysates from HeLa-TNF$\mathrm{R} 2$ cells stimulated for the indicated times with TNF-R2-specific IgG (2 $\mu \mathrm{g} / \mathrm{ml}$ ) were separated by gel filtration and the TRAF2 content of corresponding fractions were compared by immunoblotting. (G) HeLa-TNF-R2 cells were stimulated for the indicated times with TNF-R2-specific IgG (2 $\mu \mathrm{g} / \mathrm{ml})$. Total cellular content, soluble proteins and the detergent-insoluble compartment (DIC) fractions were prepared as described in Materials and Methods and analyzed with respect to TRAF2 by western blotting. (H) To thoroughly quantify the loss in the total TRAF 2 content observed in receptorstimulated cells after 18 hours, six independent experiments were analyzed. Cells were stimulated for 0,3 and 18 hours, boiled in SDS-PAGE sample buffer and analyzed by western blotting. purpose we prepared S-100 supernatants from untreated HeLaTNF-R2 cells and cells that were previously stimulated with TNF-R2-specific antibodies for 6 hours. Upon separation of the SN-100 supernatants over a superdex 200 HR10/30 column the fractions obtained were analyzed by immunoblotting. In accordance with data from the literature (Shu et al., 1996), we found that, in untreated cells, most of the cytosolic TRAF2 eluated in fractions corresponding to $300-500 \mathrm{kDa}$ (Fig. 3A), suggesting that the majority of TRAF2 is part of a multiprotein complex in HeLa-TNF-R2 cells. But more importantly, when identical amounts of protein lysates were compared, obtained from receptor-stimulated and untreated cells, we found a significant depletion of TRAF2-containing complexes in the
TNF-R2-stimulated group (Fig. 3B). TRAF2 depletion was most pronounced in the high molecular mass fractions (Fig. 3B), whereas a minority of TRAF2, which was eluted around $60 \mathrm{kDa}$, was not affected (data not shown). It is tempting to speculate that the 'monomeric' TRAF2 fraction represents a pool of TRAF2 that is unable to interact with TNF-R2. However, further studies will be necessary to clarify the importance and function of this monomeric TRAF2 fraction. No TNF-R2-dependent TRAF2 depletion was found in HeLa cells stably expressing a deletion mutant of TNF-R2 lacking the cytoplasmic domain of the molecule (Fig. 3C).

In the stable transfectants expressing CD30 (HeLa-CD30) and CD40 (HeLa-CD40), respectively, we also found a 
Fig. 4. Effect of pre- and costimulation of TNF-R2 on TNF-R1-mediated activation of NF- $\kappa \mathrm{B}$ and TNF-R1induced cell death. (A-D) HeLa-TNF-R2 cells were grown in 96-well microtiter plates $\left(15 \times 10^{3}\right.$ cells/well $)$, cultured overnight at $37^{\circ} \mathrm{C}$ and were transiently transfected the next day with a plasmid mix containing $3 \times \mathrm{NF}-\mathrm{\kappa B}$-luciferase reporter plasmid (20 ng/well), SV40 promoter-driven $\beta$-galactosidase expression plasmid (10 ng/well) and empty vector (pCR3, $120 \mathrm{ng} /$ well). 6 hours after transfection some cells $(\mathrm{A}, \mathrm{C})$ were stimulated overnight with $2 \mu \mathrm{g} / \mathrm{ml}$ anti-TNF-R2 IgG (filled bars) to allow next day analysis of TNF-R1-dependent NF- $\kappa \mathrm{B}$ activation in a situation where TRAF2 had already been depleted. For activation of TNF-R1, cells were challenged in triplicates with the indicated concentration of TNF (A) or the TNF-R1-specific agonistic mAb Htr1 (C). To analyze NF- $\kappa \mathrm{B}$ activation under costimulatory conditions (B,D), cells were stimulated with anti-TNF-R2 IgG (filled bars) and either TNF (B) or Htr1 (D). In all experiments, cells subjected to costimulation were compared with cells stimulated only with the respective concentration of TNF or Htr1 (open bars). After TNF-R1 stimulation for 6 hours, cells were lysed and assayed for luciferase and galactosidase activity. Finally, luciferase activities were normalized according to the respective galctosidase activities. (E) Effect of temporal order of TNF-R1 and TNF-R2 stimulation with respect to NF- $\mathrm{KB}$ activation and apoptosis induction. TNF-

$\mathrm{R} 2$ was stimulated for the indicated times before or after triggering of TNF-R1. For determination of NF- $\kappa \mathrm{B}$ activation $(\mathbf{O})$, cells were transfected as described above and assayed for luciferase and galactosidase activities 6 hours after TNF-R1 triggering (10 ng/ml TNF). For determination of cell viability $(\bigcirc)$, TNF-R1 was triggered overnight with $0.1 \mathrm{ng} / \mathrm{ml} \mathrm{TNF}$ in the presence of CHX $(2.5 \mu \mathrm{g} / \mathrm{ml})(\mathrm{i} . \mathrm{e}$. at a concentration of TNF that induces no cell death in the absence of TNF-R2 costimulation). The effect of TNF/anti-TNF-R2 IgG costimulation was normalized to the effect of TNF alone. (F) HeLa-TNF-R2 cells were seeded in 96-well microtiter plates at a density of $15 \times 10^{3}$ cell/well and cultured overnight at $37^{\circ} \mathrm{C}$ in the absence $(\bigcirc)$ or presence $(O)$ of anti-TNF-R2 IgG. The next day the cells were challenged with TNF $(\bigcirc, \square)$ or TNF and anti-TNF-R2 IgG $(-)$ in the presence of CHX $(2.5 \mu \mathrm{g} / \mathrm{ml})$. After overnight incubation, viable cells were quantified by crystal violet staining.

depletion of high molecular mass TRAF2-containing complexes upon stimulation with agonistic antibodies (Fig. $3 \mathrm{D}, \mathrm{E})$. In these cases we were unable to detect 'monomeric' TRAF2 even in nonstimulated cells (data not shown). Compared with HeLa-TNF-R2 cells, we observed reduced levels of TRAF2 in unstimulated cells of both HeLa-CD30 and HeLa-CD40. This correlates with the observation that, in particular, HeLa-CD30 and, to a lesser extent, HeLa-CD40, but not TNF-R2-expressing cells exerted some ligand-independent constitutive receptor signaling (data not shown), possibly caused by the overexpression of these molecules. As 'monomeric' TRAF2 represents a minor fraction of total TRAF2, it is possible that it was below the detection threshold of our western blot analysis. The 'ligand'-induced depletion of TRAF2-containing complexes started to become apparent 1 hour after receptor triggering, and was almost complete after
6 hours (Fig. 3F). Depletion of TRAF2 occurred in the absence as well as in the presence of cycloheximide [i.e. under conditions where TNF-treatment could induce apoptosis in this cell line (data not shown)].

Receptor-induced depletion of cytoplasmic TRAF2containing complexes could be caused by translocation of TRAF2 to a detergent-insoluble cellular compartment or/and by proteolytic degradation. We therefore analyzed total TRAF2 levels in cells by direct solubilization of cell pellets in SDSPAGE sample buffer and determined TRAF2 levels in cytoplasmic extracts and detergent-resistant membrane fractions. Activation of TNF-R2 resulted in transient accumulation of TRAF2 in the detergent-resistant membrane fraction after 1-3 hours (Fig. 3G,H). However, 6-18 hours after receptor stimulation, a decrease in the TRAF content of total cell lysates was observed (Fig. 3G,H) suggesting that, after the 
A

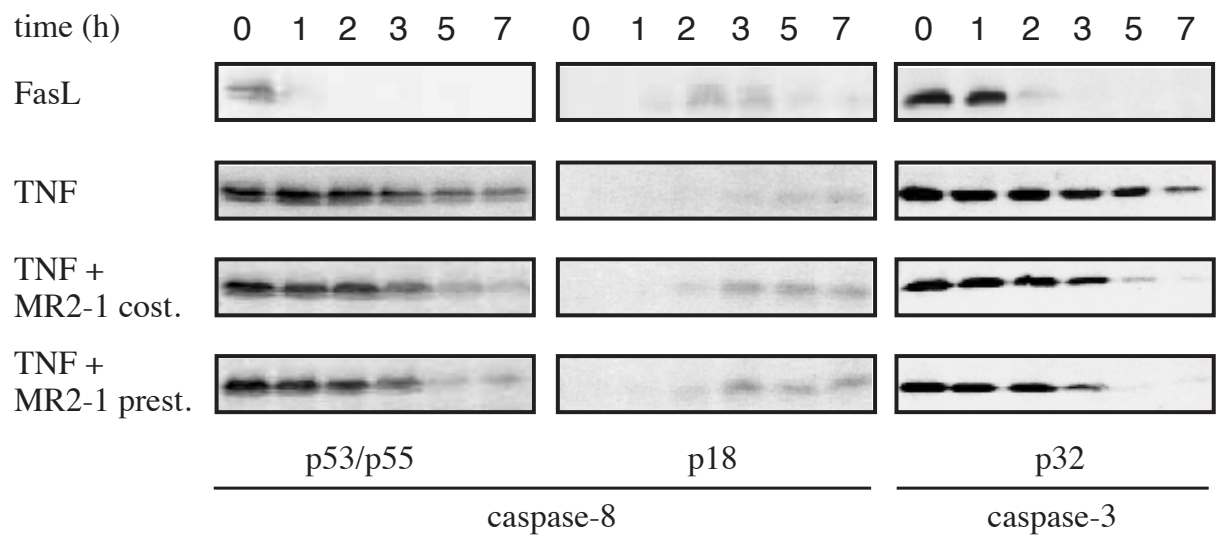

B

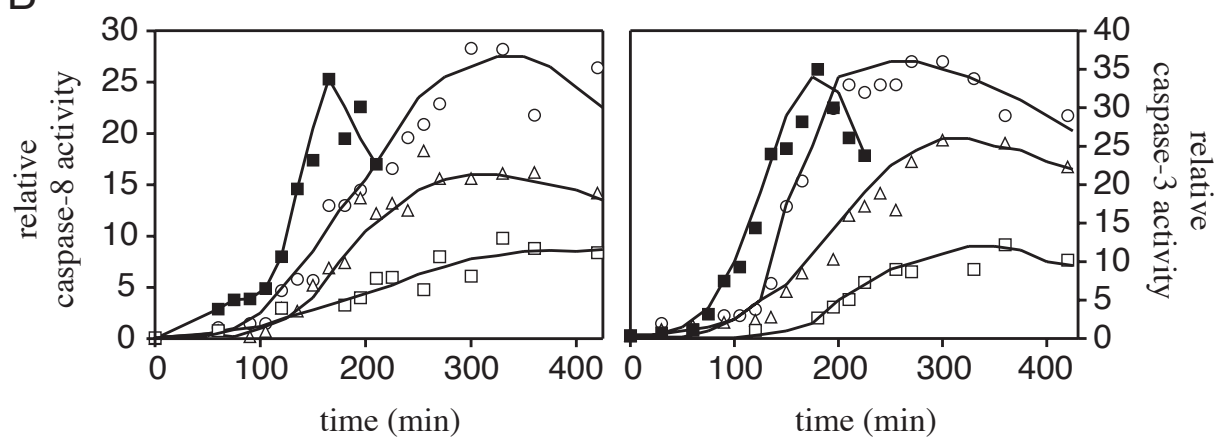

C

HeLa cells

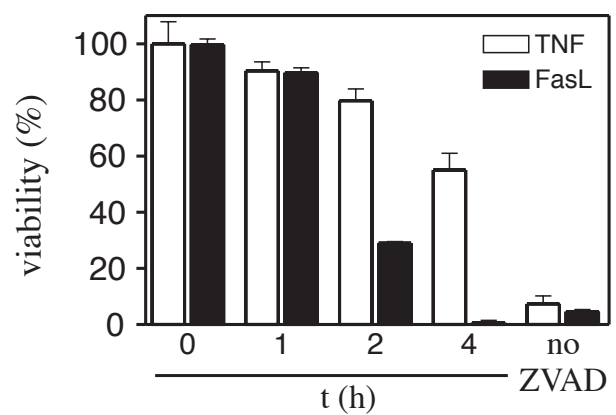

Kym-1 and SKW cells

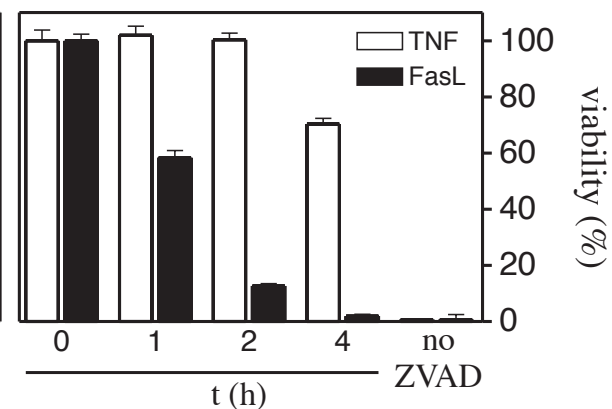

Fig. 5. Kinetics of TNF and FasLinduced caspase- 8 activation. (A) HeLaTNF-R2 cells were pretreated with $\mathrm{CHX}$ $(2.5 \mu \mathrm{g} / \mathrm{ml})$ for 3 hours. Cells were then stimulated for the indicated times with crosslinked FasL (100 ng/ml), TNF (10 $\mathrm{ng} / \mathrm{ml}$ ) alone or in combination with anti-TNF-R2 IgG $(2 \mu \mathrm{g} / \mathrm{ml})$. In an additional group, cells were stimulated with anti-TNF-R2 IgG for 6 hours before TNF treatment. Cell lysates were prepared and procaspase- 8 and -3 processing was analyzed by immunoblotting. (B) Cells were treated as described above with crosslinked FasL ( $\square)$, TNF ( $\square$ ) or TNF and antiTNF-R2 IgG (costimulation: $\triangle$; prestimulation: $\bigcirc$ ). After the indicated times, the cells were lysed and analyzed with respect to caspase- 8 and caspase- 3 activity with fluorogenic substrates. (C) HeLa cells pretreated with CHX $(2.5 \mu \mathrm{g} / \mathrm{ml})$ for 3 hours (left panel) and Kym 1 and SKW cells, respectively, (right panel) were challenged with TNF $(10 \mathrm{ng} / \mathrm{ml})$ or crosslinked FasL (100 $\mathrm{ng} / \mathrm{ml})$. After the indicated times the pan caspase-inhibitor z-VAD-fmk $(20 \mu \mathrm{M})$ was added and after overnight incubation cell viability was determined by crystal violet staining (HeLa, Kym1) or by the MTT method (SKW). first few hours of TNF-R2 stimulation, depletion of 'free' cytoplasmic TRAF2 pools was mainly caused by recruitment of the protein by TNF-R2 into a detergent-insoluble compartment, followed by TRAF2 degradation leading to sustained downregulation of this signaling molecule. Nevertheless, TNF-R2-dependent depletion of TRAF2 also seems to continue at late time points, because the total content of TRAF2 dropped down by more than $60 \%$ (Fig. $3 \mathrm{H}$ ) after 18 hours, whereas TRAF2 levels in the DIC fraction were comparable with those before stimulation (Fig. 3G). This implies that the distribution of TRAF2 between the soluble and the DIC fraction is still significantly shifted towards the DIC fraction. As an alternative to TRAF2 degradation, reduced de novo synthesis of TRAF2 could also explain the reduction of total TRAF2 protein, found at later time points, but we observed no changes in the TRAF2
mRNA content at any time after TNF-R2 stimulation (data not shown). In agreement with these findings Arch et al. have found that TRAF2 is redistributed from the cytoplasm into detergent-insoluble aggregates after co-transfection with constitutively active forms of CD30, 4-1BB and OX40 (Arch et al., 2000). In this report redistribution of TRAF2 correlated with an increased sensitivity towards TNF. Reduction in cytoplasmic TRAF2 levels after CD30 stimulation was also associated with increased TNF sensitivity in anaplastic large cell lymphoma cells (Mir et al., 2000). In accordance with the idea that the availability of cytoplasmic TRAF2 determines the TNF sensitivity, it has been shown that HeLa transfectants stably expressing increased amounts of TRAF2 have a reduced sensitivity against soluble TNF but can still be sensitized to this death ligand by TNF-R2 stimulation (Weiss et al., 1998). 

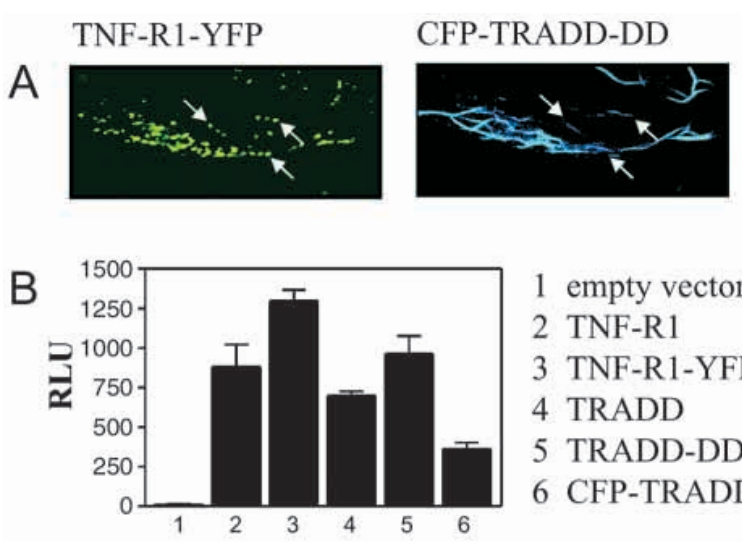

Overlay
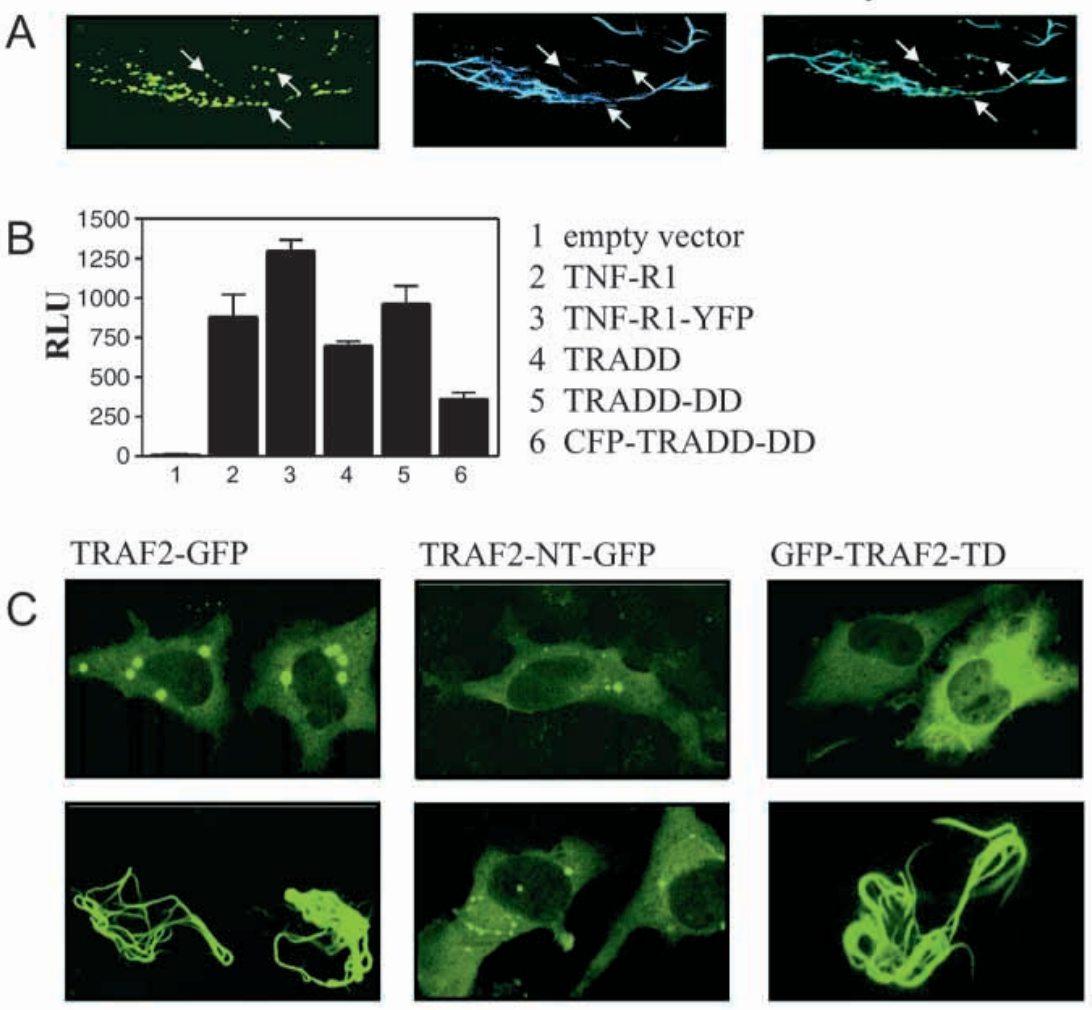

TRADD

\section{IKK1-GFP}
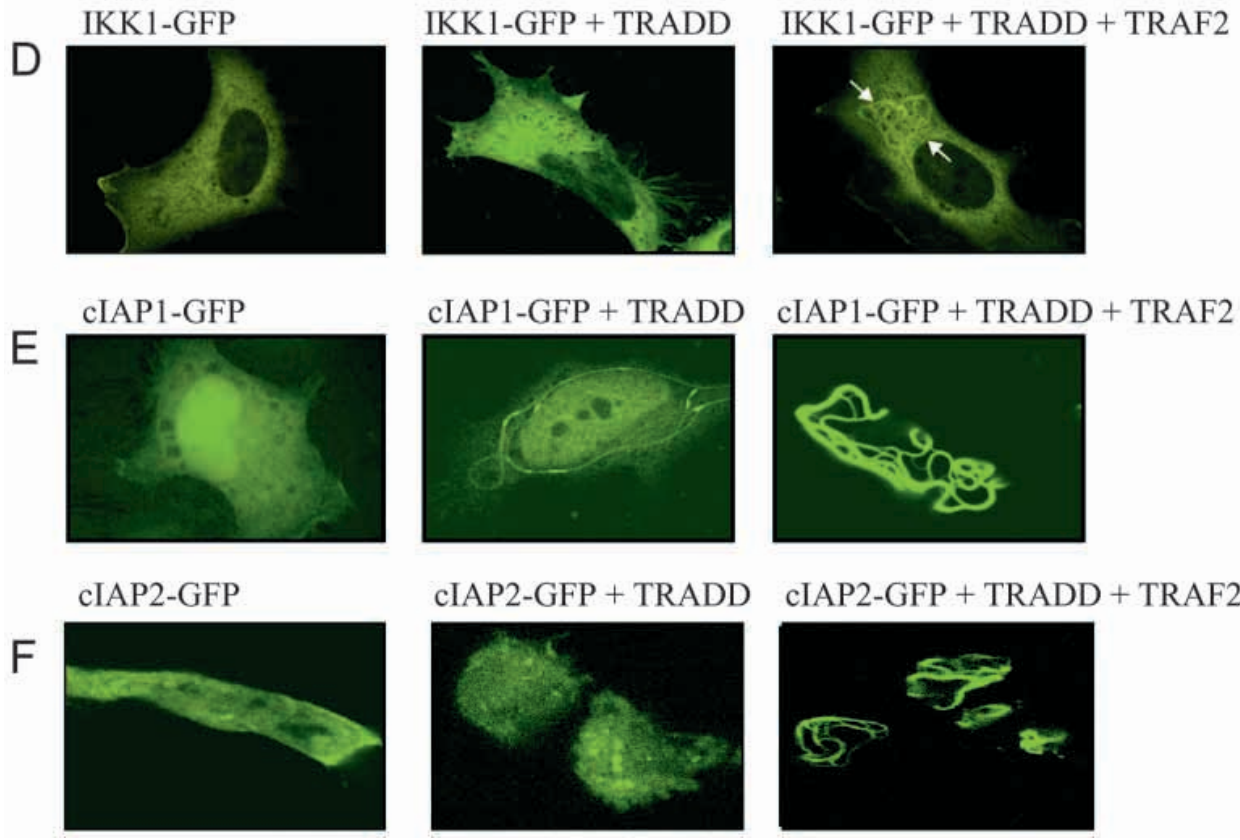

Fig. 6. (A) HeLa cells were transiently transfected with TNF-R1YFP and TRADD-CFP. To inhibit the induction of TRADD-dependent apoptosis, cells were treated with $\mathrm{z}$ VAD-fmk $(20 \mu \mathrm{M})$ immediately after transfection. One day later, transfected cells were analyzed by confocal microscopy. (B) Expression plasmids (120 ng/well) encoding the indicated proteins were transiently transfected into 293 cells along with a $3 \times \mathrm{NF}-\kappa \mathrm{B}-$ luciferase reporter plasmid (20 $\mathrm{ng} /$ well) and a SV40 promoter-driven $\beta$-galactosidase expression plasmid (10 ng/well). The next day cells were analyzed for luciferase and galactosidase activity. Luciferase activities were normalized according to the respective galctosidase activities. In all transfections z-VADfmk $(20 \mu \mathrm{M})$ was added to block apoptosis. (C) The indicated GFPtagged variants of TRAF2 were cotransfected along with empty vector or TRADD and cultured overnight in the presence of $z$-VAD-fmk $(20 \mu \mathrm{M})$. The next day, the subcellular distribution of the various GFP fusion proteins was analyzed by confocal microscopy. (D-F) The indicated combinations of expression plasmids of TRADD, TRAF2, IKK1-GFP, cIAP2-GFP and cIAP1-GFP were cotransfected and cultured overnight in the presence of $z$-VAD-fmk (20 $\mu \mathrm{M})$. The following day, the subcellular distribution of the various GFP fusion proteins was analyzed by confocal microscopy.
It has recently been shown that TRAF proteins can be the target of caspases [TRAF1 (Irmler et al., 2000), TRAF3 (Lee et al., 2001)] or the proteasome [TRAF6 (Takayanagi et al., 2000), TRAF2 (Brown et al., 2001)]. However, the ligandinduced depletion of TRAF2 observed in our system was not affected by the pan caspase-inhibitor z-VAD-fmk nor the proteasome inhibitor MG-132, even at concentrations tenfold higher than necessary to completely inhibit induction of apoptosis or activation of $\mathrm{NF}-\kappa \mathrm{B}$, respectively (data not shown).

Temporal order of stimulation of TNF-R1 and TNF-R2 determines the outcome of TNF-R1 signaling

We next analyzed the effects of TNF-R2 stimulation and TRAF2 depletion on TNF-R1-induced signaling in detail. To 
$0^{\prime}$

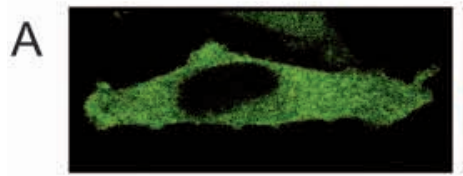

$10^{\prime}$

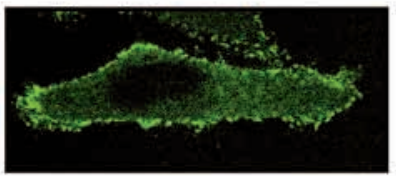

$30^{\prime}$

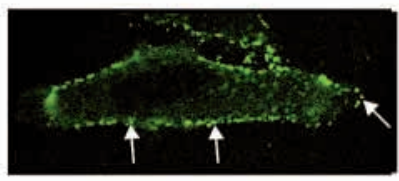

$0 \mathrm{~h}$
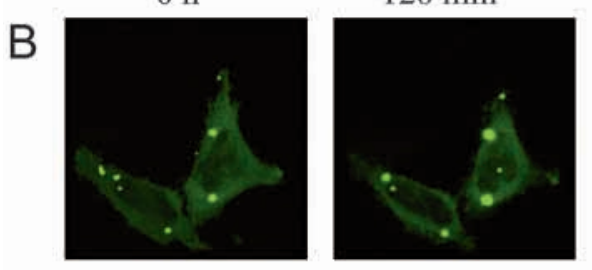

$0 \mathrm{~h}$

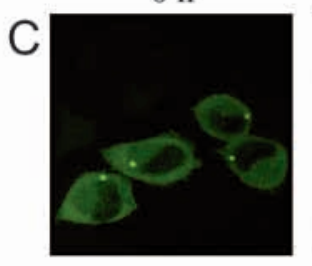

Overlay

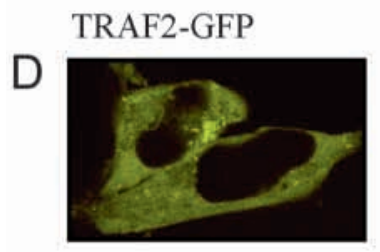

$$
\text { NM(1-20)-CFP }
$$
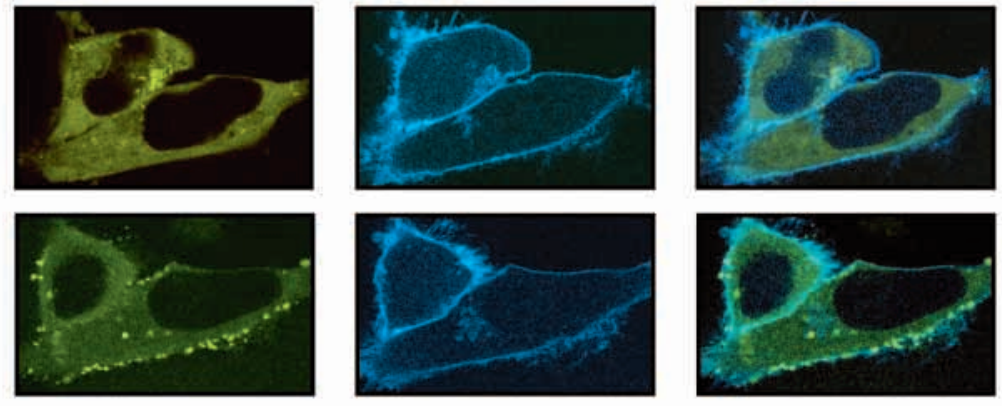

TRAF2-GFP

E
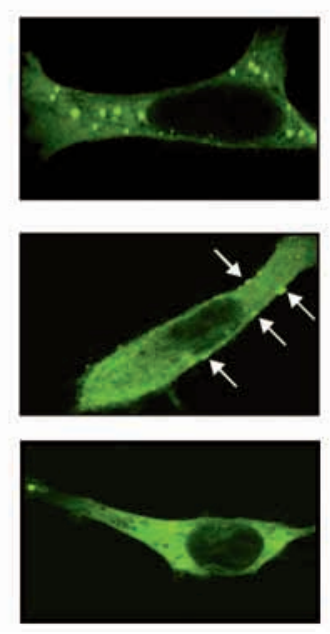

$\alpha$ TNF-R2
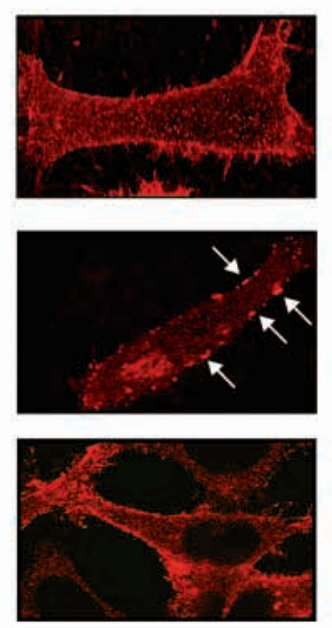

Overlay
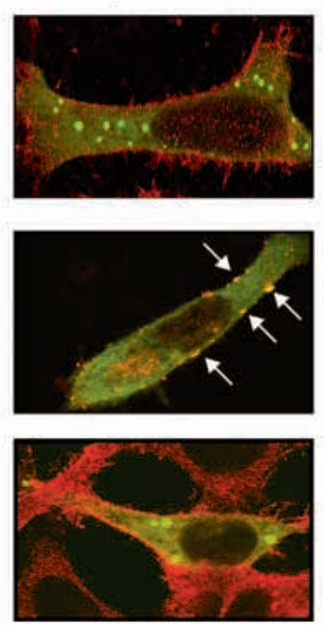

stimulated

$\alpha$ TNF-R2

$120 \mathrm{~min}$

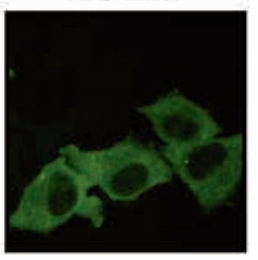

unstimulated

unstimulated

stimulated

$\alpha$ TNF-R2
Fig. 7. Ligand-induced alterations of TRAF-2 localization in living cells. (A,D,E) TNF-R2 signaling was induced in living Hela-TNF$\mathrm{R} 2$ cells using an agonistic TNFR2-specific antiserum (A). The distribution of TRAF2-YFP was analyzed online both prior to stimulation and for a further 30 minutes after stimulation by confocal microscopy. TRAF2 accumulated in small granular structures in response to TNF-R2 activation, examples of which are indicated with arrows. In contrast, a normal rabbit control serum (B) or the CD30-specific Ki-1 antibody (C) had no effect on the distribution of TRAF2. (D) HeLaTNF-R2 cells were transfected with a TRAF2-GFP expression plasmid along with pECFP-Mem encoding a fusion protein consisting of the N-terminal 20 amino acids of neuromodulin and CFP. The next day, nonstimulated or TNF-R2-stimulated (1 hour, 2 $\mu \mathrm{g} / \mathrm{ml} \alpha \mathrm{TNF}-\mathrm{R} 2 \mathrm{IgG}$ ) living cells were analyzed by confocal microscopy. (E) HeLa-TNF-R2 cells were transfected with a TRAF2-GFP expression plasmid. The following day, nonstimulated, TNF-R2-stimulated (1 hour, 2 $\mu \mathrm{g} / \mathrm{ml} \alpha \mathrm{TNF}-\mathrm{R} 2 \mathrm{IgG}$ ) and TNFtreated (1 hour, $20 \mathrm{ng} / \mathrm{ml} \mathrm{TNF}$ ) living cells were analyzed by confocal microscopy. Endogenous TNF-R2 expression was detected by immunofluorescence using a TNF-R2-specific polyclonal rabbit antiserum. Examples of colocalized TNF-R2 and TRAF2GFP are indicated with arrows. analyze TNF-R1-induced NF- $\mathrm{B}$ activation in a situation where TRAF2 was already depleted, we selectively prestimulated TNF-R2 with agonistic antibodies overnight, followed by TNF-R1 activation using either the TNF-R1specific agonistic mAb HTR1 or soluble TNF. Under these conditions TNF-R1-mediated activation of a NF- $\kappa \mathrm{B}-d$ riven reporter gene was found to be reduced by up to $90 \%$ over a wide range of TNF (HTR1) concentrations (Fig. 4A,C). Comparable results were obtained in the presence of low doses of $\mathrm{CHX}(2.5 \mu \mathrm{g} / \mathrm{ml})$ [i.e. under conditions where apoptosis is induced by TNF-R1 but protein synthesis is only modestly inhibited (data not shown)].

The situation was different when both TNF receptors were stimulated at the same time. Under these conditions there was no sign of TNF-R2-dependent inhibition of TNF-R1-induced NF- $\kappa \mathrm{B}$ activation (Fig. 4B,D). Again, the presence of CHX did not change the outcome of the experiment (data not shown). As stimulation of TNF-R1 induces transient activation of the IKK complex within 5-15 minutes, which in turn leads to sustained NF- $\mathrm{KB}$ binding activity in the nucleus, it is feasible 
A
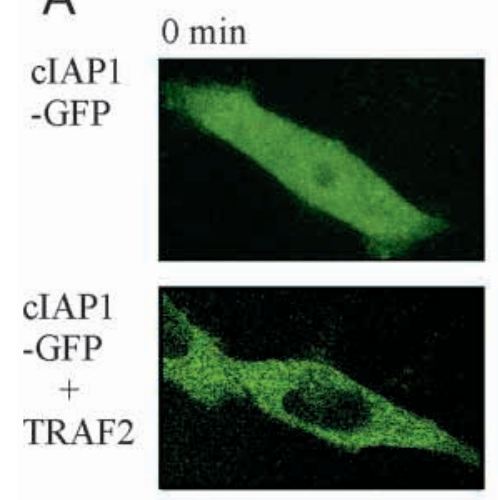

$5 \mathrm{~min}$
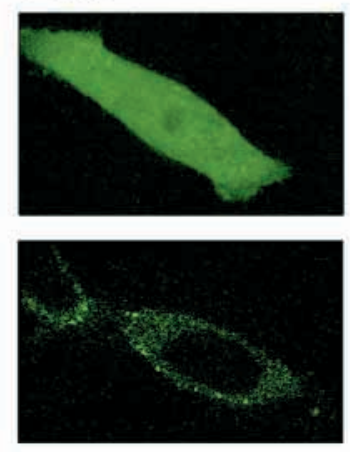

B
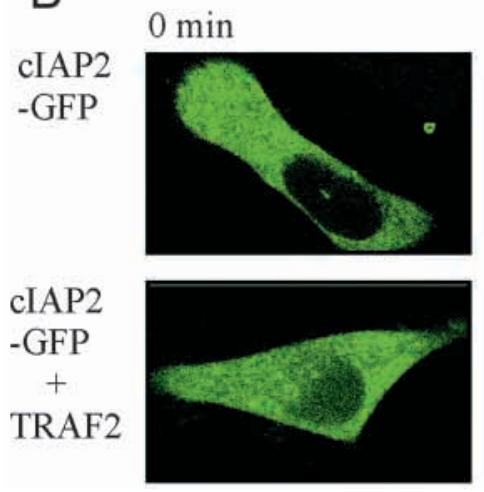

$5 \mathrm{~min}$
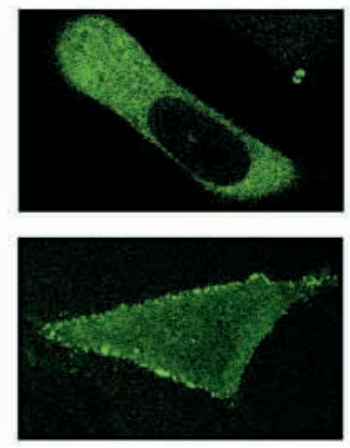

$15 \mathrm{~min}$
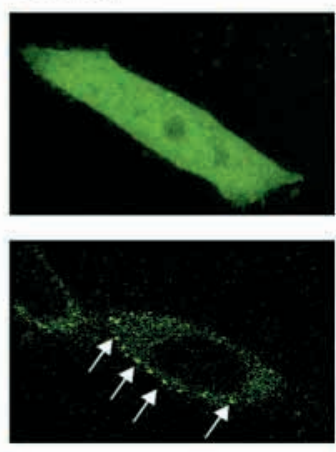

$15 \mathrm{~min}$
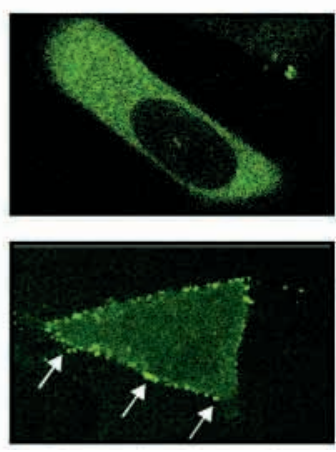

Fig. 8. Recruitment of cIAP1 and cIAP2 into the TNF-R2 complex critically depends on TRAF2 in living cells. HeLa-TNF-R2 cells were transfected with expression plasmids encoding for cIAP1(NT)-GFP (A) or cIAP1(NT)-GFP (B), alone or in combination with an expression construct for full-length TRAF2. The following day, distribution of the GFP chimeras was both analyzed prior to stimulation $(2 \mu \mathrm{g} / \mathrm{ml} \alpha \mathrm{TNF}-\mathrm{R} 2 \mathrm{IgG})$ and monitored online for 15 minutes after stimulation using confocal microscopy. Examples of ligandinduced alterations in the localization of the GFP fusion proteins are indicated with arrows.

TNF-R2 stimulation accelerates caspase-8 activation by TNF-R1

In transient co-transfection studies it has been found that TRAF2 can be part of a complex containing cIAP1, cIAP2 and TRAF1, which inhibits TNF-R1mediated apoptosis (Wang et al., 1998). TNF-R2-induced TRAF2 depletion/ degradation could lead to inhibition of the formation of this anti-apoptotic complex and consequently to an enhancement of TNF-R1-induced activation of caspase-8. Under prestimulation conditions, where cytosolic TRAF2 is significantly depleted, the formation of the antiapoptotic complex might be affected in two ways: (1) by reduced NF-KBdependent induction of TRAF1, cIAP1 and cIAP2; and (2) by the lack of TRAF2 itself. In contrast, under costimulatory conditions only the lack of available TRAF2 may limit TRAF1/TRAF2/cIAP1/cIAP2 complex formation. However, when this is the case, the kinetics of TNF-R1-induced caspase- 8 activation have to be slow or delayed to give the TNF-R2-dependent TRAF2 depletion time to take place and to interfere with the formation of, or to disrupt, the TRAF1/2/cIAP $1 / 2$ complex.

Slow or delayed caspase-8 activation by 'activated' TNF-R1 is not selfevident. In the case of Fas-mediated apoptosis, a quantitative activation of procaspase- 8 within a few minutes has been described (Medema et al., 1997). In HeLa cells treated with CHX, that the slowly proceeding TNF-R2-mediated TRAF2 depletion (Fig. 3) does not interfere with TNF-R1-induced NF- $\mathrm{KB}$ activation when both receptors are triggered at the same time. Indeed, the kinetics of TNF-R2-induced TRAF2 depletion (Fig. 3F) are in good agreement with the time dependency of NF-KB-inhibitory effect of TNF-R2 prestimulation. While TRAF2 depletion requires 1-3 hours, half maximal inhibition of TNF-R1-induced NF-KB activation by prestimulation of TNF-R2 became evident after about 2 hours (Fig. 4E). In accordance with the anti-apoptotic function of the NF- $\mathrm{KB}$ pathway, prestimulation of TNF-R2 for 8 hours resulted in a significantly greater enhancement of TNF-R1induced cell death than a simultaneous stimulation of both TNF receptors (Fig. 4F). Nevertheless, as already shown in Figs 1 and 2, there is a clear enhancement of TNF-R1-induced cell death under costimulatory conditions where TNF-R1-induced NF- $\mathrm{KB}$ activation was not inhibited. Obviously, the apoptotic TNF-R1/TNF-R2 crosstalk is not only related to inhibition of the NF- $\kappa \mathrm{B}$ pathway, but also based on an additional TNFR2-dependent, NF-kB-independent mechanism, capable of enhancing TNF-R1-induced cell death at the posttranscriptional level. caspase- 8 processing is detectable by cleavage of its full-length $55-$ and $53 \mathrm{kDa}$ isoforms leading to disappearance of the respective proteins and concomitant appearance of the active p18 subunit of caspase-8.

As shown in Fig. 5A, almost all full-length caspase-8 was processed 1 hour after apoptosis-induction in HeLa-Fas cells by treatment with Fas-specific agonistic mAbs in the presence of CHX. In contrast, caspase-8 activation in TNF/CHX-treated cells was detectable only after 3 hours and complete activation was not achieved at all (Fig. 5A). Similar results were obtained by directly measuring caspase activity (Fig. 5B). The differential kinetics and extent of caspase- 8 activation by stimulation of TNF-R1 and Fas were also observed in Jurkat, Kym1 (TNF-R1) and SKW (Fas) cells, where induction of apoptosis does not require the presence of CHX (data not shown). Similar results were obtained when the activity of the excutioner caspase-3 was monitored (Fig. 5A,B) or when crosslinked soluble FasL was used instead of Fas-specific agonistic antibodies (data not shown). The differences in kinetics and extent of caspase activation by TNF and antiApo1/FasL correlated with the variations in time, when the broad range caspase inhibitor z-VAD-fmk had to be added to 
Table 1. Depletion of cytoplasmic TRAF2-GFP, cIAP1GFP and cIAP2-GFP after TNF-R2 stimulation

\begin{tabular}{lccc}
\hline Experiment no. & $\begin{array}{c}\text { Depletion of } \\
\text { TRAF2-GFP }(\%)\end{array}$ & $\begin{array}{c}\text { Depletion of } \\
\text { cIAP1-GFP }(\%)\end{array}$ & $\begin{array}{c}\text { Depletion of } \\
\text { cIAP2-GFP (\%) }\end{array}$ \\
\hline 1 & 26 & 45 & 81 \\
2 & 36 & 69 & 57 \\
3 & 37 & 73 & 66 \\
4 & 37 & 47 & 55 \\
5 & 39 & 61 & 52 \\
6 & 45 & 70 & 27 \\
Average & 37 & 52 & 56
\end{tabular}

To calculate the depletion of cytoplasmic fluorescent proteins, fluorescence intensities in a cytoplasmic area were determined before and 30 minutes after receptor stimulation ( $\alpha$ TNF-R2). All measurements were corrected for bleaching effects, which were obtained by analyses of nonstimulated cells. Bleaching effects in all experiments were between 3 and $12 \%$ with an average of 7.3\%. Depletion of TRAF2-GFP was determined after transfection of a 1:1 mixture of a TRAF2-GFP expression plasmid and empty vector, and depletion of cIAP1/2-GFP was determined after transfection with a 1:1 mixture of expression plasmids encoding TRAF2 and cIAP1/2-GFP.

prevent apoptosis. After 1 hour of Fas/Apo1 stimulation, zVAD-fmk treatment was able to rescue only $60-70 \%$ of the cells and after 3 hours there was no protective effect at all (Fig. 5C). In contrast, upon TNF-R1 triggering a significant proportion of the challenged cells were protected by z-VADfmk even after 8 hours (Fig. 5C). Hence, under costimulatory conditions, the slow and ineffective activation of caspase- 8 by TNF via TNF-R1 would allow TNF-R2-induced TRAF2 degradation to interfere with the action of the anti-apoptotic cIAP/TRAF complex. In accordance with this concept, we found that costimulation and, to an even greater extent, prestimulation of TNF-R2 enhanced TNF-R1-induced caspase- 8 activation (Fig. 5A,B).

TRAF2 is necessary for the recruitment of CIAP1 and ClAP2 to TRADD

To investigate the role of TRAF2 for the recruitment of antiapoptotic factors into the TNF-R1 signaling complex we used confocal fluorescence microscopy and GFP-tagged forms of components of this complex. As shown in Fig. 6A, cotransfection of TNF-R1-YFP and CFP-TRADD-DD led to a colocalization of both molecules. Interestingly, overexpression of CFP-TRADD-DD (Fig. 6A) or full-length myc-tagged TRADD (data not shown) resulted in the formation of TRADD filaments. As transiently overexpressed CFP-TRADD-DD and full-length myc-tagged TRADD showed effects similar to those of overexpressed TNF-R1 or ligand-stimulated TNF-R1, such as activation of the NF-кB (Fig. 6B), JNK and apoptosis pathways (data not shown) (Hsu et al., 1996), we postulate that TRADD filaments have some properties related to receptorrecruited endogenous TRADD. Importantly, we found that GFP-tagged IKK1, a part of the NF-кB-inducing IKK complex, was also partially recruited into the TRADD filaments in the presence of cotransfected TRAF2 (Fig. 6D). This is in accordance with a recent study using $\mathrm{TRAF}^{-1-}$ fibroblasts, which showed that TRAF2 is necessary to recruit the IKK complex into the TNF-R1 signaling complex (Devin et al., 2001). Again this emphasizes our assumption that TRADD filaments are functionally equivalent to TNF/TNFR1/TRADD signaling complexes.
We therefore used the artificial filament formation of TRADD to investigate the interaction of TRADD with TRAF2, cIAP1 and cIAP2. We first studied the interaction of untagged TRADD and GFP fusion protein of TRAF2. N-terminally as well as C-terminally GFP-linked TRAF2 behaved similarly to untagged TRAF2 in respect to homo- and heterooligomerization, NF- $\mathrm{B}$ activation and binding of a TNF-R2 GST fusion protein (data not shown). In unstimulated cells, TRAF2 N-terminally linked to GFP (TRAF2-GFP) was found in the cytoplasm (Fig. 6C). In addition, TRAF2-GFP accumulates in a few, large round patches (Fig. 6C). Most likely these TRAF2-GFP patches are artefacts caused by overexpression and may represent the proportion of transiently expressed TRAF2 molecules that is responsible for ligandindependent activation of $\mathrm{NF}-\kappa \mathrm{B}$ and JNK. We found that TRAF2-GFP was recruited into TRADD filaments under critical involvement of its TRAF domain (Fig. 6C). Important for the idea that TRAF2 depletion by non-death receptors interferes with the formation/action of TNF-R1/TRADDrecruitable anti-apoptotic cIAP/TRAF-complexes, we found that TRAF2 dramatically enhanced the recruitment of cIAP1GFP and cIAP2-GFP into TRADD filaments. While in cells coexpressing TRADD and cIAP1-GFP or cIAP2-GFP, only a small proportion of the GFP-tagged IAP proteins were associated with the TRADD filaments, coexpression of TRAF2 leads to a quantitative recruitment of cIAP1-GFP and cIAP2GFP into TRADD complexes (Fig. 6E,F). Obviously, TRAF2 has an essential role in the recruitment of cIAP1 and cIAP2 into the TNF-R1/TRADD complex, data that are in good accordance with the postulated importance of the TRAF1/ TRAF2/cIAP1/cIAP2 complex discussed above and with previous data showing ligand-induced recruitment of cIAP1 into the TNF-R1 signaling complex (Shu et al., 1996).

TRAF2 is necessary for the recruitment of cIAP1 and clAP2 to the receptor complex of TNF-R2 in living cells

Next we studied directly alterations of the intracellular localization of GFP-linked TRAF2 induced by stimulation of TNF-R2. Real-time monitoring of TRAF2-GFP by confocal laser microscopy showed that, in HeLa-TNF-R2 cells, TRAF2GFP becomes compartmentalized in small aggregates in response to selective activation of TNF-R2 (Fig. 7A), whereas $\mathrm{Ki}-1$ or a control IgG preparation had no effect on HeLa-TNFR2 cells (Fig. 7B,C). Similar results were obtained upon stimulation of CD30 or CD40. The TNF-R2-induced TRAF2GFP containing aggregates represent complexes of TNF-R2 and TRAF2-GFP, as is evident from colocalization with the plasma membrane marker CFP-Mem (Fig. 7D) and TNF-R2specific antibodies (Fig. 7E). Of particular interest, soluble TNF, which is unable to properly activate TNF-R2 in HeLaTNFR2 cells, failed to induce receptor/TRAF2-GFP complexes (Fig. 9B). Importantly, cIAP1-GFP and cIAP2-GFP (data not shown) as well as GFP fusion proteins of the IAP1/2 binding domain for TRAF2 (Fig. 8) were recruited into the TNF-R2 signaling complex only when TRAF2 was coexpressed. This is in accordance with data from the literature showing ligand-independent interaction of TNF-R2 and cIAP proteins in the presence of TRAF2 in transient overexpression experiments (Rothe et al., 1995). Analysis of cytoplasmic cIAP1-GFP and cIAP2-GFP revealed a significant depletion of 


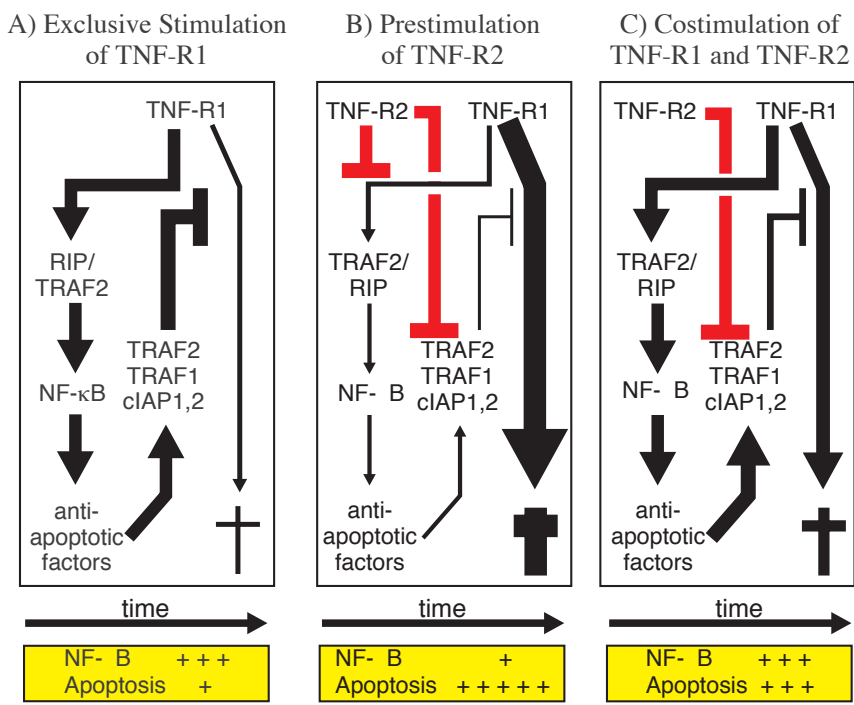

Fig. 9. Model of the apoptotic TNF-R1/TNF-R2 crosstalk. (A) Exclusive stimulation of TNF-R1. (B) Prestimulation of TNFR2. (C) Costimulation of both TNF receptors. For details see Discussion.

these molecules 30 minutes after TNF-R2 stimulation (Table 1). In six independent experiments, reduction of cytoplasmic cIAP-GFP proteins ranged between 45 and $81 \%$ (average $52 \%$ for cIAP1-GFP and 56\% for cIAP2-GFP. Depletion of IAP1/2GFP in the presence of TRAF2 was typically more efficient than depletion of TRAF2-GFP (Table 1). Thus, the possibility arises that TRAF2/cIAP complexes interact better with TNFR2 than with IAP-free TRAF2 complexes. However, it cannot be ruled out that this is caused by higher expression of TRAF2YFP compared with the non-tagged TRAF2 mediating TNFR2-recruitment of TRAF2/cIAP-GFP complexes in the IAP depletion experiments. Further experiments will be necessary to clarify this.

\section{Discussion}

Based on the presented results we suggest the following model (Fig. 9) for the enhancement of TNF-R1-induced cell death by stimulation of non-death-domain-containing members of the TNF receptor superfamily that interact with TRAF2.

Exclusive stimulation of TNF-R1 (Fig. 9A) with soluble TNF immediately activates the NF- $\kappa \mathrm{B}$ pathway leading to the synthesis of NF- $\mathrm{KB}$-dependent genes. However, the formation of TNF-R1 complexes that can signal apoptosis occurs with a delay of several hours. This is evident from the time course of TNF-induced caspase-8 activation (Fig. 5). TNF-induced NF$\kappa \mathrm{B}$ activation results in the upregulation of anti-apoptotic factors such as TRAF1 (Schwenzer et al., 1999; Wang et al., 1998), cIAP1 (Wang et al., 1998), cIAP2 (Chu et al., 1997; Wang et al., 1998), cFLIP (Kreuz et al., 2001), and Bfl-1/A1 (Lee et al., 1999). An anti-apoptotic function has been published for all these proteins and, with the exception of Bfl1/A1, all these molecules can interact with TRAF2. With respect to the apoptotic TNF-R1/TNF-R2 crosstalk, Bfl1/A1 can most likely be neglected as it acts independently of TRAF2, is barely detectable in HeLa cells and is not induced by TNF in this cell line (data not shown). Although cFLIP can bind to TRAF2 it is certainly not directly involved in the apoptotic TNF-R1/TNF-R2 crosstalk for several reasons: (1) In Jurkat-TNF-R2 cells, in which the apoptotic crosstalk occurs in the absence of CHX, cFLIP is not detectable and is not induced by TNF. (2) In many cell lines, including HeLa cells, which have been used in this study, at least low concentrations of $\mathrm{CHX}$ are necessary for the induction of death receptor-induced apoptosis. It is commonly assumed that this reflects the necessity to downregulate an antiapoptotic factor with rapid turnover below a critical threshold concentration. A prime candidate for this anti-apoptotic factor is cFLIP, as we and others have recently found that cFLIP has a rapid turnover and is therefore its expression is highly sensitive to metabolic inhibitors such actinomycin D or CHX (Griffith et al., 1998; Kreuz et al., 2001; Leverkus et al., 2000; Wajant et al., 2000). It is noteworthy that the requirement for this compound for induction of apoptosis remains unchanged upon prestimulation of TNF-R2, indicating that this $\mathrm{CHX}$ sensitive factor is distinct from the NF-кB-dependent antiapoptotic factors mediating the apoptotic TNF-R1/TNF-R2 crosstalk. Moreover, the apoptotic TNF-R1/TNF-R2 crosstalk is FLIP-independent, which is in agreement with the facts that TNF- but not Fas- and TRAIL-induced apoptosis are enhanced by prestimulation of TNF-R2, and that apoptosis induction in Hela cells by all these reagents requires CHX. Therefore, according to our model, we suggest that the anti-apoptotic factors cIAP1, cIAP2, and TRAF1 regulate the apoptotic TNF-R1/TNF-R2 crosstalk. All these factors bind to TRAF2 and become recruited into the TNF-R1 signaling complex, thereby preventing efficient activation of caspase-8. The outcome is a modest apoptotic response. Hence, the balance between protective mechanisms and activation of caspase-8, the trigger of the apoptotic program, is shifted towards apoptosis only in a small fraction of the cells. cIAP1 and cIAP2 bind and inhibit caspase- 3 and caspase-7 but not caspase-8 (Roy et al., 1997). Thus, it is tempting to speculate that in the TNF-R1 signaling complex TRAF1/2-recruited IAPs and TRADD/FADD-recruited caspase- 8 come into close proximity, which allows IAP proteins to inhibit caspase- 8 activation, possibly without a direct interaction between the two. In accordance with the scenario described above, Wang

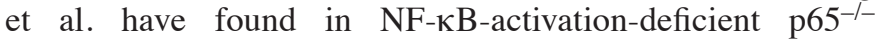
fibroblasts that the individual transient overexpression of TRAF1, TRAF2, cIAP1 and cIAP2 has no significant inhibitory effect on TNF-induced apoptosis, whereas the coexpression of these molecules protects the cells from TNFinduced cell death (Wang et al., 1998).

The consequences of TNF-R1 stimulation, as described above, are quite different when TNF-R1 becomes triggered several hours after activation of TNF-R2 (Fig. 9B): prestimulated TNF-R2 has then depleted TRAF2. This has two consequences for TNF-R1 signaling. First, owing to the important role of TRAF2 in TNF-R1-induced NF-кB activation (Devin et al., 2000; Devin et al., 2001; Tada et al., 2001), this pathway is inhibited (Fig. 4) and therefore the production of anti-apoptotic factors is reduced. Second, low levels of pre-existing or still reduced levels of induced antiapoptotic proteins cannot work properly as they need the support of TRAF2 [e.g. for targeting to the TNF-R1 signaling complex (Fig. 6)]. Reduced NF- $\kappa \mathrm{B}$ activation and impaired formation of TRAF1/TRAF2/cIAP1/cIAP2 complexes fails to 
inhibit caspase- 8 activation and the apoptotic pathway becomes activated in all cells.

The situation changes again when TNF-R1 is stimulated together with TNF-R2 (Fig. 9C). TNF-R1-induced NF-кB activation per se is not inhibited under these conditions (Fig. 4), as this process is clearly faster than depletion/degradation of TRAF2. Hence, TNF-R1 triggering leads to normal production of anti-apoptotic factors. However, the biosynthesis of these factors needs time, and during this time TRAF2 is depleted/degraded by TNF-R2. Thus, although anti-apoptotic factors are produced they cannot act properly as they need TRAF2 for their action at the post-transcriptional level (see above). The outcome is an enhanced but, compared with the prestimulation scenario, reduced sensitization of the cells for the apoptotic effects of TNF-R1.

All the experiments described in this study and all experiments related to TNF receptor cooperation and TRAF2 depletion described in the literature were performed in cancer cell lines. Thus, the question of the physiological relevance of TRAF2 depletion and TNF receptor crosstalk was raised. In this regard, the available literature points to at least two physiological processes that could be related to this TNF receptor cooperation. First, induction of activation-induced cell death in $\mathrm{CD}^{+} \mathrm{T}$ cells. In accordance with an involvement of TRAF2 depletion and TNF receptor cooperation, it has been shown in TNF-R1 (Speiser et al., 1996) and TNF-R2 (Zheng et al., 1995) knockout mice that both receptors can have a major impact on this TNF-mediated apoptotic process. Moreover, Sarin et al. have shown that TNF-R1 and TNF-R2 synergistically induce cell death in T cell blasts in vitro (Sarin et al., 1995). Second, TNF-R2-induced TRAF2 depletion and inhibition of TNF-R1-induced NF- $\mathrm{KB}$ activation under nonapoptotic conditions (Fig. 4) could explain the finding that in a mylelin oligodendrocyte glycoprotein (MOG) model of experimental autoimmune encephalomyelitis (EAE) TNF- or TNF-R1-deficiency led to delay in disease onset, whereas TNF-R2-deficiency results in a more severe phenotype (Eugster et al., 1999).

This work was supported by Deutsche Forschungsgemeinschaft Grant Wa 1025/3-1 and Sonderforschungsbereich 495 project A5.

\section{References}

Arch, R. H., Gedrich, R. W. and Thompson, C. B. (2000). Translocation of TRAF proteins regulates apoptotic threshold of cells. Biochem. Biophys. Res. Commun. 272, 936-945.

Beg, A. A., Sha, W. C., Bronson, R. T., Ghosh, S. and Baltimore, D. (1995). Embryonic lethality and liver degeneration in mice lacking the RelA component of NF-kappa B. Nature 376, 167-170.

Bigda, J., Beletsky, I., Brakebusch, C., Varfolomeev, Y., Engelmann, H., Bigdam, J., Holtmann, H. and Wallach, D. (1994). Dual role of the p75 tumor necrosis factor (TNF) receptor in TNF cytotoxicity. J. Exp. Med. 180, 445-460.

Brown, K. D., Hostager, B. S. and Bishop, G. A. (2001). Differential signaling and tumor necrosis factor receptor-associated factor (TRAF) degradation mediated by CD40 and the Epstein-Barr virus oncoprotein latent membrane protein 1 (LMP1). J. Exp. Med. 193, 943-954.

Chan, F. K. and Lenardo, M. J. (2000). A crucial role for p80 TNF-R2 in amplifying p60 TNF-R1 apoptosis signals in T lymphocytes. Eur. J. Immunol. 30, 652-660.

Chu, Z. L., McKinsey, T. A., Liu, L., Gentry, J. J., Malim, M. H. and Ballard, D. W. (1997). Suppression of tumor necrosis factor-induced cell death by inhibitor of apoptosis c-IAP2 is under NF-kappaB control. Proc. Natl. Acad. Sci. USA 94, 10057-10062.
Declercq, W., Denecker, G., Fiers, W. and Vandenabeele, P. (1998). Cooperation of both TNF receptors in inducing apoptosis: involvement of the TNF receptor-associated factor binding domain of the TNF receptor 75 . J. Immunol. 161, 390-399.

Devin, A., Cook, A., Lin, Y., Rodriguez, Y., Kelliher, M. and Liu, Z. (2000). The distinct roles of TRAF2 and RIP in IKK activation by TNF-R1: TRAF2 recruits IKK to TNF-R1 while RIP mediates IKK activation. Immunity $\mathbf{1 2}$ 419-429.

Devin, A., Lin, Y., Yamaoka, S., Li, Z., Karin, M. and Liu, Z. (2001). The alpha and beta subunits of IkappaB kinase (IKK) mediate TRAF2-dependent IKK recruitment to tumor necrosis factor (TNF) receptor 1 in response to TNF. Mol. Cell. Biol. 21, 3986-3994.

Duckett, C. S. and Thompson, C. B. (1997). CD30-dependent degradation of TRAF2: implications for negative regulation of TRAF signaling and the control of cell survival. Genes Dev. 11, 2810-2821.

Eugster, H. P., Frei, K., Bachmann, R., Bluethmann, H., Lassmann, H. and Fontana, A. (1999). Severity of symptoms and demyelination in MOGinduced EAE depends on TNFR1. Eur. J. Immunol. 29, 626-632.

Grell, M., Scheurich, P., Meager, A. and Pfizenmaier, K. (1993). TR60 and TR80 tumor necrosis factor (TNF)-receptors can independently mediate cytolysis. Lymphokine Cytokine Res. 12, 143-148.

Grell, M., Douni, E., Wajant, H., Lohden, M., Clauss, M., Maxeiner, B., Georgopoulos, S., Lesslauer, W., Kollias, G., Pfizenmaier, K. and Scheurich, P. (1995). The transmembrane form of tumor necrosis factor is the prime activating ligand of the $80 \mathrm{kDa}$ tumor necrosis factor receptor. Cell 83, 793-802.

Grell, M., Wajant, H., Zimmermann, G. and Scheurich, P. (1998). The type 1 receptor (CD120a) is the high-affinity receptor for soluble tumor necrosis factor. Proc. Natl. Acad. Sci. USA 95, 570-575.

Grell, M., Zimmermann, G., Gottfried, E., Chen, C. M., Grunwald, U., Huang, D. C., Wu Lee, Y. H., Durkop, H., Engelmann, H., Scheurich, P. et al. (1999). Induction of cell death by tumour necrosis factor (TNF) receptor 2, CD40 and CD30: a role for TNF-R1 activation by endogenous membrane-anchored TNF. EMBO J. 18, 3034-3043.

Griffith, T. S., Chin, W. A., Jackson, G. C., Lynch, D. H. and Kubin, M. Z. (1998). Intracellular regulation of TRAIL-induced apoptosis in human melanoma cells. J. Immunol. 161, 2833-2840.

Heller, R. A., Song, K., Fan, N. and Chang, D. J. (1992). The p70 tumor necrosis factor receptor mediates cytotoxicity. Cell 70, 47-56.

Hess, S. and Engelmann, H. (1996). A novel function of CD40: induction of cell death in transformed cells. J. Exp. Med. 183, 159-167.

Hsu, H., Shu, H. B., Pan, M. G. and Goeddel, D. V. (1996). TRADD-TRAF2 and TRADD-FADD interactions define two distinct TNF receptor 1 signal transduction pathways. Cell 84, 299-308.

Irmler, M., Steiner, V., Ruegg, C., Wajant, H. and Tschopp, J. (2000). Caspase-induced inactivation of the anti-apoptotic TRAF1 during Fas ligand-mediated apoptosis. FEBS Lett. 468, 129-133.

Kelliher, M. A., Grimm, S., Ishida, Y., Kuo, F., Stanger, B. Z. and Leder, P. (1998). The death domain kinase RIP mediates the TNF-induced NFkappaB signal. Immunity 8, 297-303.

Kreuz, S., Siegmund, D., Scheurich, P. and Wajant, H. (2001). NF-kappaB inducers upregulate cFLIP, a cycloheximide-sensitive inhibitor of death receptor signaling. Mol. Cell. Biol. 21, 3964-3973.

Lee, H. H., Dadgostar, H., Cheng, Q., Shu, J. and Cheng, G. (1999). NFkappaB-mediated up-regulation of Bcl-x and Bfl-1/A1 is required for CD40 survival signaling in B lymphocytes. Proc. Natl. Acad. Sci. USA 96, 91369141.

Lee, Z. H., Lee, S. E., Kwack, K., Yeo, W., Lee, T. H., Bae, S. S., Suh, P. G. and Kim, H. H. (2001). Caspase-mediated cleavage of TRAF3 in FasLstimulated Jurkat-T cells. J. Leukocyte Biol. 69, 490-496.

Leverkus, M., Neumann, M., Mengling, T., Rauch, C. T., Brocker, E. B., Krammer, P. H. and Walczak, H. (2000). Regulation of tumor necrosis factor-related apoptosis-inducing ligand sensitivity in primary and transformed human keratinocytes. Cancer Res. 60, 553-559.

Li, Q., van Antwerp, D., Mercurio, F., Lee, K. F. and Verma, I. M. (1999). Severe liver degeneration in mice lacking the IkappaB kinase 2 gene. Science 284, 321-325.

Locksley, R. M., Killeen, N. and Lenardo, M. J. (2001). The TNF and TNF receptor superfamilies: integrating mammalian biology. Cell 104, 487-501.

Makris, C., Godfrey, V. L., Krahn-Senftleben, G., Takahashi, T., Roberts, J. L., Schwarz, T., Feng, L., Johnson, R. S. and Karin, M. (2000). Female mice heterozygous for IKK gamma/NEMO deficiencies develop a dermatopathy imilar to the human X-linked disorder incontinentia pigmenti 1336. Mol. Cell 5, 969-979. 
Medema, J. P., Scaffidi, C., Kischkel, F. C., Shevchenko, A., Mann, M., Krammer, P. H. and Peter, M.E. (1997). FLICE is activated by association with the CD95 death-inducing signaling complex (DISC). EMBO J. 16, 2794-2804.

Medvedev, A. E., Sundan, A. and Espevik, T. (1994). Involvement of the tumor necrosis factor receptor p75 in mediating cytotoxicity and gene regulating activities. Eur. J. Immunol. 24, 2842-2849.

Mir, S. S., Richter, B. W. and Duckett, C. S. (2000). Differential effects of CD30 activation in anaplastic large cell lymphoma and Hodgkin disease cells. Blood 96, 4307-4312.

Pimentel-Muinos, F. X. and Seed, B. (1999). Regulated commitment of TNF receptor signaling: a molecular switch for death or activation. Immunity 11, 783-793.

Rothe, M., Pan, M. G., Henzel, W. J., Ayres, T. M. and Goeddel, D. V. (1995). The TNFR2-TRAF signaling complex contains two novel proteins related to baculoviral inhibitor of apoptosis proteins. Cell 83, 1243-1252.

Roy, N., Deveraux, Q. L., Takahashi, R., Salvesen, G. S. and Reed, J. C. (1997). The c-IAP-1 and c-IAP-2 proteins are direct inhibitors of specific caspases. EMBO J. 16, 6914-6925.

Rudolph, D., Yeh, W. C., Wakeham, A., Rudolph, B., Nallainathan, D., Potter, J., Elia, A. J. and Mak, T. W. (2000). Severe liver degeneration and lack of NF-kappaB activation in NEMO/IKKgamma-deficient mice. Genes Dev. 14, 854-862.

Sarin, A., Conan-Cibotti, M. and Henkart, P. A. (1995). Cytotoxic effect of TNF and lymphotoxin on T lymphoblasts. J. Immunol. 155, 3716-3718.

Schmidt-Supprian, M., Bloch, W., Courtois, G., Addicks, K., Israel, A., Rajewsky, K. and Pasparakis, M. (2000). NEMO/IKK gamma-deficient mice model incontinentia pigmenti. Mol. Cell 5, 981-992.

Schneider, P., Holler, N., Bodmer, J. L., Hahne, M., Frei, K., Fontana, A. and Tschopp, J. (1998). Conversion of membrane-bound Fas(CD95) ligand to its soluble form is associated with downregulation of its proapoptotic activity and loss of liver toxicity. J. Exp. Med. 187, 1205-1213.

Schwenzer, R., Siemienski, K., Liptay, S., Schubert, G., Peters, N., Scheurich, P., Schmid, R. M. and Wajant, H. (1999). The human tumor necrosis factor (TNF) receptor-associated factor 1 gene (TRAF1) is upregulated by cytokines of the TNF ligand family and modulates TNFinduced activation of NF-kappaB and c-Jun N-terminal kinase. J. Biol. Chem. 274, 19368-19374.

Shu, H. B., Takeuchi, M. and Goeddel, D. V. (1996). The tumor necrosis factor receptor 2 signal transducers TRAF2 and c- IAP1 are components of the tumor necrosis factor receptor 1 signaling complex. Proc. Natl. Acad. Sci. USA 93, 13973-13978

Speiser, D. E., Sebzda, E., Ohteki, T., Bachmann, M. F., Pfeffer, K., Mak, T. W. and Ohashi, P. S. (1996). Tumor necrosis factor receptor p55 mediates deletion of peripheral cytotoxic T lymphocytes in vivo. Eur. $J$. Immunol. 26, 3055-3060.

Tada, K., Okazaki, T., Sakon, S., Kobarai, T., Kurosawa, K., Yamaoka, S., Hashimoto, H., Mak, T. W., Yagita, H., Okumura, K. et al. (2001). Critical roles of TRAF2 and TRAF5 in TNF-induced NF-kB activation and protection from cell death. J. Biol. Chem. 276, 36530-36534.

Takayanagi, H., Ogasawara, K., Hida, S., Chiba, T., Murata, S., Sato, K., Takaoka, A., Yokochi, T., Oda, H., Tanaka, K. et al. (2000). T-cell- mediated regulation of osteoclastogenesis by signalling cross- talk between RANKL and IFN-gamma. Nature 408, 600-605.

Tanaka, M., Fuentes, M. E., Yamaguchi, K., Durnin, M. H., Dalrymple, S. A., Hardy, K. L. and Goeddel, D. V. (1999). Embryonic lethality, liver degeneration, and impaired NF-kappa B activation in IKK-beta-deficient mice. Immunity 10, 421-429.

Tartaglia, L. A., Rothe, M., Hu, Y. F. and Goeddel, D. V. (1993). Tumor necrosis factor's cytotoxic activity is signaled by the p55 TNF receptor. Cell 73, 213-216.

Vandenabeele, P., Declercq, W., Vanhaesebroeck, B., Grooten, J. and Fiers, W. (1995). Both TNF receptors are required for TNF-mediated induction of apoptosis in PC60 cells. J. Immunol. 154, 2904-2913.

Vercammen, D., Vandenabeele, P., Declercq, W., van de Craen, M., Grooten, J. and Fiers, W. (1995). Cytotoxicity in L929 murine fibrosarcoma cells after triggering of transfected human $\mathrm{p} 75$ tumour necrosis factor (TNF) receptor is mediated by endogenous murine TNF. Cytokine 7 , 463-470.

Wajant, H., Johannes, F. J., Haas, E., Siemienski, K., Schwenzer, R., Schubert, G., Weiss, T., Grell, M. and Scheurich, P. (1998). Dominantnegative FADD inhibits TNFR60-, Fas/Apo1- and TRAIL-R/Apo2mediated cell death but not gene induction. Curr. Biol. 8, 113-116.

Wajant, H., Grell, M. and Scheurich, P. (1999). TNF receptor associated factors in cytokine signaling. Cytokine Growth Factor Rev. 10, 15-26.

Wajant, H., Haas, E., Schwenzer, R., Mühlenbeck, F., Kreuz, S., Schubert, G., Grell, M., Smith, C. and Scheurich, P. (2000). Inhibition of death receptor-mediated gene induction by a cycloheximide-sensitive factor occurs at the level of or upstream of Fas-associated death domain protein (FADD). J. Biol. Chem. 275, 24357-24366.

Wajant, H., Henkler, F. and Scheurich, P. (2001). The TNF-receptorassociated factor family: scaffold molecules for cytokine receptors, kinases and their regulators. Cell Signal. 13, 389-400.

Wallach, D., Varfolomeev, E. E., Malinin, N. L., Goltsev, Y. V., Kovalenko, A. V. and Boldin, M. P. (1999). Tumor necrosis factor receptor and Fas signaling mechanisms. Annu. Rev. Immunol. 17, 331-367.

Wang, C. Y., Mayo, M. W., Korneluk, R. G., Goeddel, D. V. and Baldwin, A.S., Jr (1998). NF-kappaB antiapoptosis: induction of TRAF1 and TRAF2 and c-IAP1 and c- IAP2 to suppress caspase-8 activation. Science 281, 16801683.

Weiss, T., Grell, M., Hessabi, B., Bourteele, S., Müller, G., Scheurich, P. and Wajant, H. (1997). Enhancement of TNF receptor p60-mediated cytotoxicity by TNF receptor p80: requirement of the TNF receptorassociated factor-2 binding site. J. Immunol. 158, 2398-2404.

Weiss, T., Grell, M., Siemienski, K., Muhlenbeck, F., Durkop, H., Pfizenmaier, K., Scheurich, P. and Wajant, H. (1998). TNFR80dependent enhancement of TNFR60-induced cell death is mediated by TNFR-associated factor 2 and is specific for TNFR60. J. Immunol. 161, 3136-3142.

Yang, J., Lin, Y., Guo, Z., Cheng, J., Huang, J., Deng, L., Liao, W., Chen, Z., Liu, Z. and Su, B. (2001). The essential role of MEKK3 in TNF-induced NF-kappaB activation. Nat. Immunol. 2, 620-624.

Zheng, L., Fisher, G., Miller, R. E., Peschon, J., Lynch, D. H. and Lenardo, M. J. (1995). Induction of apoptosis in mature T cells by tumour necrosis factor. Nature 377, 348-351. 